\title{
Rift-Related Morphology of the Afar Depression
}

\author{
Giacomo Corti, lan D. Bastow, Derek Keir, Carolina Pagli, \\ and Elizabeth Baker
}

\begin{abstract}
The Afar Depression is a subaerial triple junction between the Nubian, Somalian and Arabian Plates, the only place where the final stages of continental break-up can be observed on-land. In spite of the region being hot and inhospitable, scientists have carried out fundamental work in this unique geological setting over the last few decades. We have long-known that rifting began on large-scale border faults that now bound the Afar Depression but what role magma played in the development of this incipient ocean basin was not clear. However, in recent years, it has been revealed that repeated dike intrusions together with normal faulting accommodate extension producing a landscape dominated by spectacular fresh fault scarps and active volcanic edifices that have been created during episodic tectonic, volcano-tectonic and purely volcanic events. Observations from Ethiopia have fundamentally changed the way we think about continental break-up. The challenge now is to take what we have learned and apply it to the geological record of the rifted margins elsewhere on Earth.
\end{abstract}

\section{Keywords}

Afar $\bullet$ Rifting $\bullet$ Normal faulting $\bullet$ Diking $\bullet$ Graben $\bullet$ Volcano

\subsection{Introduction}

The Afar Depression is a triangular-shaped area of rifting at the triple junction between the Nubian, Somalian and Arabian plates (Figs. 15.1 and 15.2). Covering an area of

G. Corti (凶)

Consiglio Nazionale delle Ricerche, Istituto di Geoscienze e Georisorse, Via G. La Pira, 4, 50121 Florence, Italy

e-mail: giacomo.corti@unifi.it

\section{I.D. Bastow}

Department of Earth Science and Engineering, Imperial College London, South Kensington Campus, London SW7 2AZ, UK

\section{Keir}

National Oceanography Centre Southampton, University of Southampton, Southampton SO14 3ZH, UK

\section{Pagli}

School of Geography, Earth and Environmental Sciences,

Plymouth University, Plymouth PL4 8AA, UK

C. Pagli

Dipartimento di Scienze della Terra, Università di Pisa, Via Santa Maria, 53, 56126 Pisa, Italia

E. Baker

Shell, Houston, TX 77079-1197, USA $\sim 200,000 \mathrm{~km}^{2}$ Afar is up to $\sim 300 \mathrm{~km}$ wide in the south and $\sim 600 \mathrm{~km}$ long from south to north. Elevation drops uniformly from $\sim 1,000 \mathrm{~m}$ in the south-west to below sea level in the north (Danakil depression) and in the east, where the shores of Lake Asal, fluctuating at around $155 \mathrm{~m}$ below sea level, represent the lowest subaerial point of the African continent. Superimposed on this topography are young volcanic landforms that only exceptionally stand $500 \mathrm{~m}$ above the rift floor. The Afar lowland hosts one of the most hostile environments on Earth. Maximum temperatures are, even in the coldest months, well above $30^{\circ} \mathrm{C}$ and can exceed $50{ }^{\circ} \mathrm{C}$ during the summer wet season. Dallol, at the northern tip of Afar, has the highest average annual temperature for an inhabited location: $34{ }^{\circ} \mathrm{C}$ between 1960 and 1966 . Rainfall is rare, averaging typically less than $200 \mathrm{~mm}$ per year. The Afar Depression is an endorheic basin: the main waterflow into the area is the Awash River, which flows north-eastward through southern Afar where it ends in a chain of interconnected lakes, the last of which is Lake Abhe. These saline lakes contain almost the only water in the region. 


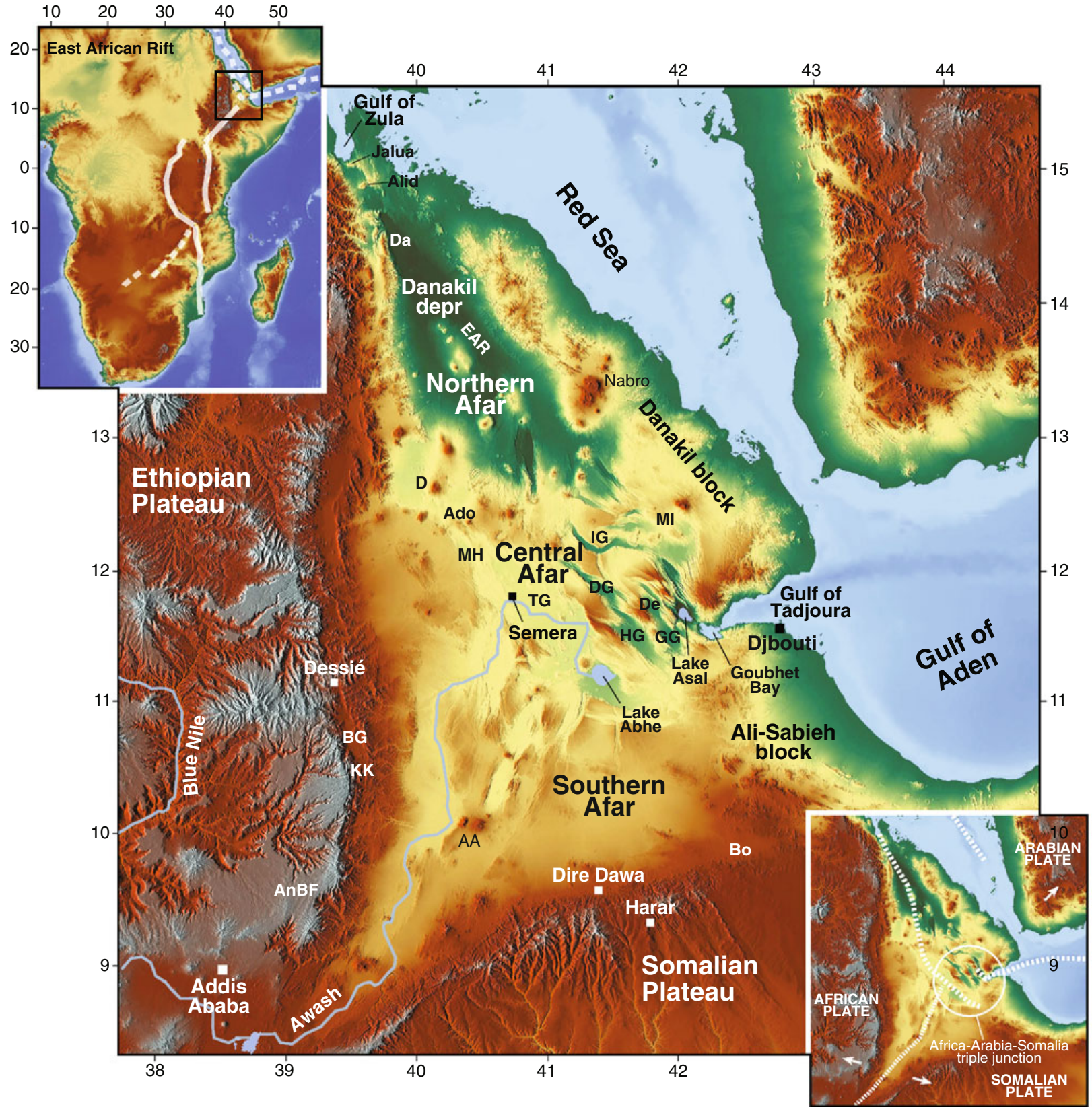

Fig. 15.1 Digital elevation model of the Afar Depression and surrounding areas (data from the Shuttle Radar Topography Mission, SRTM; resolution $90 \mathrm{~m}$ ). Inset on the top left shows the extent of the system of rift valley composing the East African Rift. Inset on the bottom right shows the plate kinematic setting of the region; dashed lines indicate plate boundaries and white arrows illustrate plate

The Afar Depression is separated from the Ethiopian and Somalian plateaus by major fault escarpments (Figs. 15.1 and 15.3). Separation from the Red Sea and Gulf of Aden is defined less dramatically by the low relief of the Danakil block (also called Danakil Alps) and the even more subdued hills of the Ali-Sabieh block. To the north, Afar narrows in the kinematics. Black and white squares indicate major towns. AA AleyuAmoissa; Ado Ado Ale; $A n B F$ Ankober border fault; $B G$ Borkena graben; Bo Borama; $D$ Dabbahu; Da Dallol; De Der'Ela graben; $D G$ Dobi graben; EAR Erta Ale range; $G G$ Gaddale graben; $H G$ Hanle graben; $I G$ Immino graben; $M H$ Manda-Hararo rift; $M I$ Manda-Inakir rift; $T G$ Tendaho graben

Danakil depression between the Danakil block and the Ethiopian escarpment, which connects the Afar lowland to the Gulf of Zula. The Gulf of Tadjoura separates the Ali-Sabieh and Danakil blocks, connecting Afar to the Gulf of Aden. However, as is the case everywhere in Afar, young volcanic centres prevent marine waters from flooding the region. 
Fig. 15.2 Tectonic setting of the Afar Depression (modified after Keir et al. 2011). Solid black lines show Oligocene-Miocene border faults of the Red Sea, Gulf of Aden and East African rifts. Red segments show the QuaternaryRecent subaerial rift axes, and green triangles show Holocene volcanoes. Dashed lines show the Tendaho-Goba'ad Discontinuity (TGD). Gray circles show large earthquakes during 1973-2012 sourced from the National Earthquake Information Centre (NEIC) catalogue. Earthquake focal mechanisms are from the Global Centroid Moment Tensor (CMT) catalogue. The black dashed line defines the boundaries of the Danakil microplate. The arrows show the motion of the Danakil microplate (McClusky et al. 2010). Cyan lines with letters indicate the traces of cross sections illustrated in Fig. 15.3

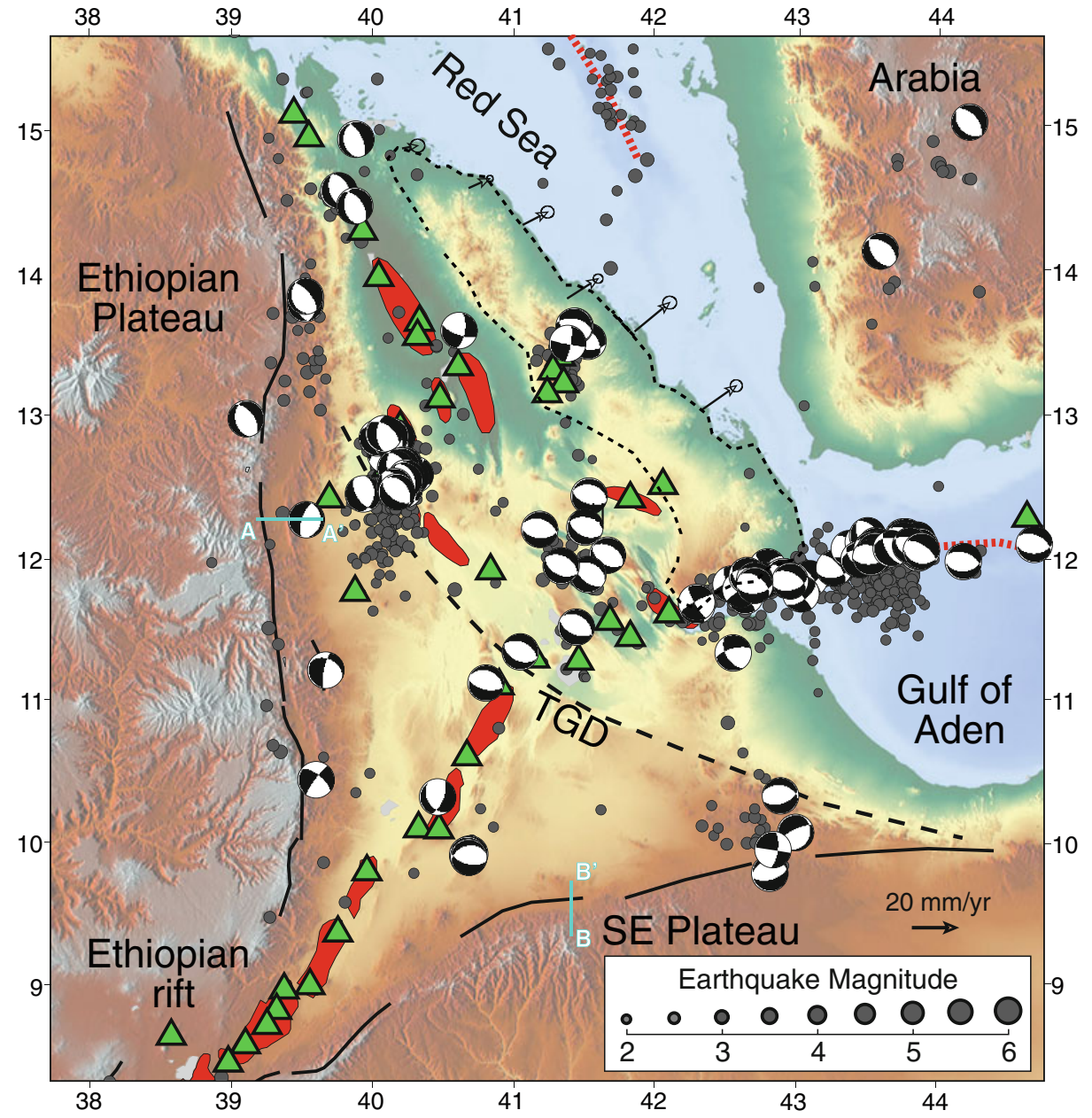

In the following sections, we describe the different physiographic provinces of Afar focusing on the morphologic expression of the main tectonic-magmatic processes related to continental rifting and break-up.

\subsection{Western and Southern Rift Escarpments}

The Ethiopian, Somalian and Yemen plateaus are part of the so-called African Superswell, a wide region of anomalously high topography comprising the East African, Arabian and southern African Plateaus as well as a bathymetric swell in the south-eastern Atlantic Ocean basin (Nyblade and Robinson 1994). This anomalous topography results from strong uplift during the Cenozoic, with up to $\sim 2 \mathrm{~km}$ rock uplift since $\sim 30 \mathrm{Ma}$ (e.g. Pik et al. 2003). Both plateaus are capped with $\sim 2 \mathrm{~km}$ of Oligocene-Miocene thick sequences of flood basalts and rhyolites, with interbedded sedimentary sequences (Hoffman et al. 1997). Together with the anomalous uplift, this voluminous volcanism has been related to the presence of one or more 'traditional' narrow (e.g. Ebinger and Sleep 1998; Rogers et al. 2000) or, more likely, a broad low wave speed thermal anomaly beneath Ethiopia (e.g. Benoit et al. 2006; Furman et al. 2006; Bastow et al. 2008; Ritsema et al. 2011; Hansen et al. 2012; Rooney et al. 2012a, b, 2013).

The elevated plateaus are abruptly separated from the Afar Depression by discontinuous boundary faults that give rise to major fault escarpments that are the continuation of the margins of the Red Sea and Gulf of Aden (Wolfenden et al. 2005; Figs. 15.3 and 15.4). The faults are normally $\sim 60 \mathrm{~km}$ long, widely spaced and characterised by large vertical offsets $(>1 \mathrm{~km}$ ), accommodating a drop in elevation from 2,000 to $3,000 \mathrm{~m}$ at the ridgeline of the escarpments to less than $1,000 \mathrm{~m}$ in the marginal areas of the Afar Depression (Wolfenden et al. 2005). Geochronological constraints suggest that the marginal faults were activated at 26-31 Ma on the western margin of Afar (i.e. Red Sea rift; e.g. Ayalew et al. 2006; Wolfenden et al. 2005) and likely at 
Fig. 15.3 The western Afar margin south of Dese (a) and in the Ankober region (b) (Photos D. Keir)
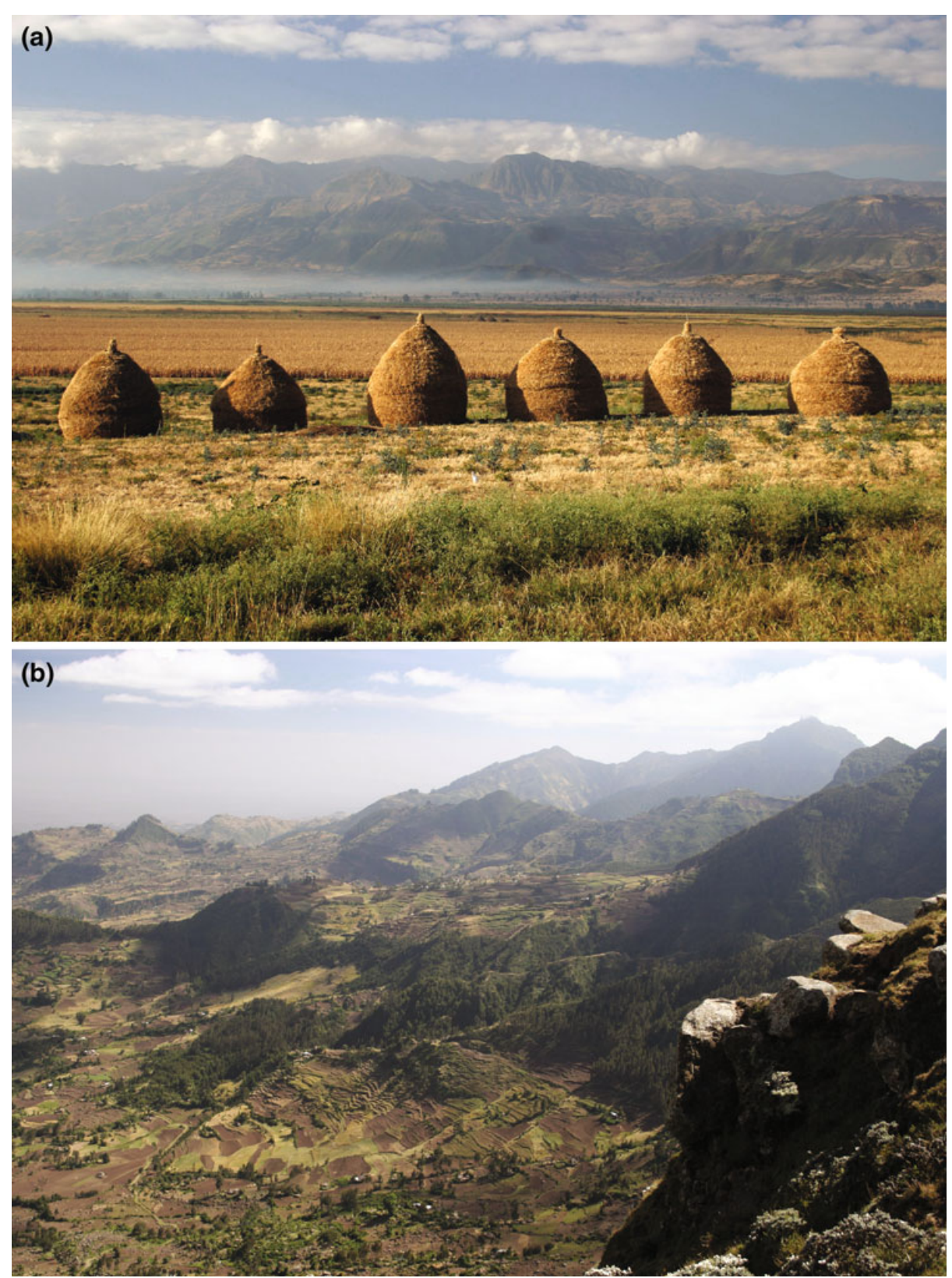

33-34 Ma on the southern margin following rift activation all along the Gulf of Aden (e.g. Leroy et al. 2012). Their activity has been interpreted to have decreased with time starting from the Late Miocene, as extension-related deformation progressively migrated from the rift margins towards the centre of the rift depression, reflecting a process of strain localisation as rifting proceeds to continental break-up (e.g. Wolfenden et al. 2005). The crest of the escarpment is a major drainage divide. To the west, the majority of rivers feed the Nile watershed and provide the majority of fertile sediments so important for agriculture in Sudan and Egypt. To the east, the largely ephemeral rivers plummet down the steep topography of the rift margin, causing severe denudation creating badlands and hummocky terrain that averages $40 \mathrm{~km}$ in width between the floor of Afar and the crest of the present escarpments (e.g. Mohr 1978).

Different rift architecture and morphology characterise the western (Ethiopian) and southern (Somalian) escarpments (e.g. Beyene and Abdelsalam 2005). The Ethiopian escarpment is characterised by an overall rift-ward tilting (Fig. 15.4), which has been interpreted as resulting from a first episode of down-warping of the Afar Depression followed by subsequent marginal faulting (Zanettin and JustinVisentin 1975; Kazmin et al. 1980). This tilting is more 
Fig. 15.4 Schematic geological cross sections across the western and southern Afar margins (after Beyene and Abdelsalam 2005). The traces of the cross sections are shown in Fig. 15.2

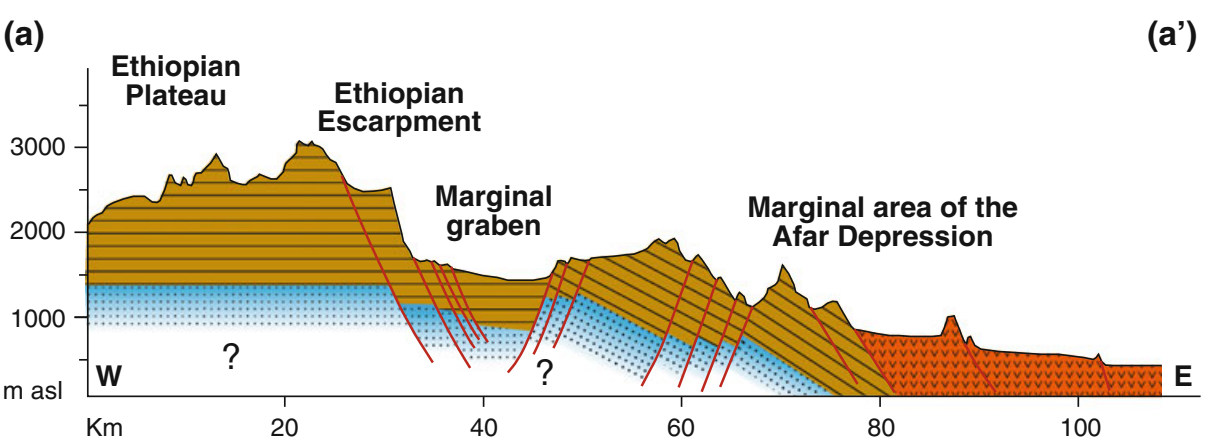

(b)

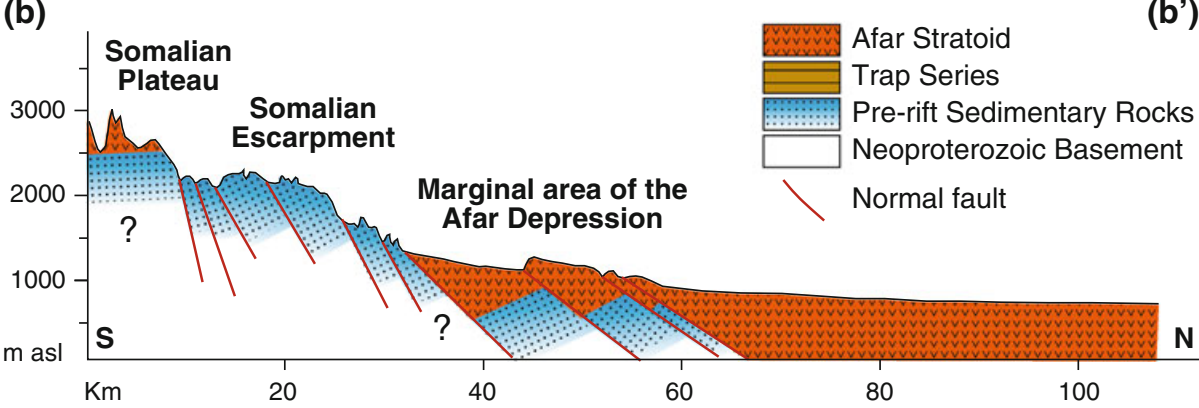

evident in the easternmost faulted blocks, where it gives rise to hogback-like structures; in the internal part of the margin, tilting is less developed as it is overprinted by development of marginal grabens (Figs. 15.4 and 15.5). These grabens, typically $10-20 \mathrm{~km}$ wide and some tens of $\mathrm{km}$ long, are filled with sediments of at least Pliocene-Quaternary age (Kazmin 1972; Chorowicz et al. 1999); they represent secondary features associated with major boundary fault systems (e.g. Corti 2012). In plan view, their en-echelon arrangement likely reflects a oblique component of extensional deformation during margin development, as also suggested by geological analysis (Chorowicz et al. 1999). The southern termination of the Ethiopian escarpment is at the Ankober border fault system, a major fault system that characterises the structurally complex 'corner' between the $\mathrm{NE}$ trending MER and the N-S trending Red Sea rift (Fig. 15.2; Wolfenden et al. 2004). Although the activity of the marginal faults is believed to have decreased with time as a result of migration of deformation towards the rift axis, the prominent morphology of the major normal faults (with clear morphotectonic indicators of recent activity, such as fresh scarps and triangular facets; Fig. 15.5; Chorowicz et al. 1999) and significant seismic activity testify an ongoing tectonic activity of the major fault escarpments. The most important earthquakes in the region struck the Kara Kore area, south of Dese, where a seismic sequence during MaySeptember 1961 produced two main shocks with $M_{L}>6.4$, seven $>5.0$ and more than 3,500 with $M_{L}>3.5$ (e.g. Gouin 1979). These events produced heavy alterations in the landscape, with numerous landslides and a 12-15 km-long piedmont scarp in unconsolidated materials along the escarpment of the Borkena graben with vertical differential displacement up to $2 \mathrm{~m}$, depth of 5-7 $\mathrm{m}$ and width at the surface over $1 \mathrm{~m}$ (Gouin 1979; Fubelli and Dramis 2011). Significant seismic activity has been also recorded by the EAGLE network of seismic stations in the period from October 2001 to January 2003 along the complex Ankober border fault system (Keir et al. 2006a, b).

The southern (Somalian) escarpment differs from the western margin of Afar in that it is characterised by a lack of marginal basins and faulted blocks tilting away from the rift centre and a domino-style faulting that gives rise to minor half grabens only (Morton and Black 1975; Pizzi and Pontarelli 2007) (Fig. 15.4). The margin is marked by isolated volcanic centres aligned along the main structures; these volcanic centres are more common in the south-western portion of the margin, close to the MER (Beyene and Abdelsalam 2005). The presence of numerous elbows and wind gaps on the main river courses indicate a strong structural control on the local drainage network, with movements on faults inducing a large number of river captures (Acocella et al. 2011). Different from what is observed at the western escarpment, preliminary geological analysis in the Harar-Dire Dawa area suggests that tectonic activity along the Somalian escarpment decreased significantly in the Middle-Late Pleistocene (Pizzi and Pontarelli 2007). However, relatively minor clusters of earthquake are relatively common at the intersection between the southern margin of Afar and the eastern margin of the MER, and also near Borama on the Ethiopia-Somalia border (Keir et al. 2006a, b). 


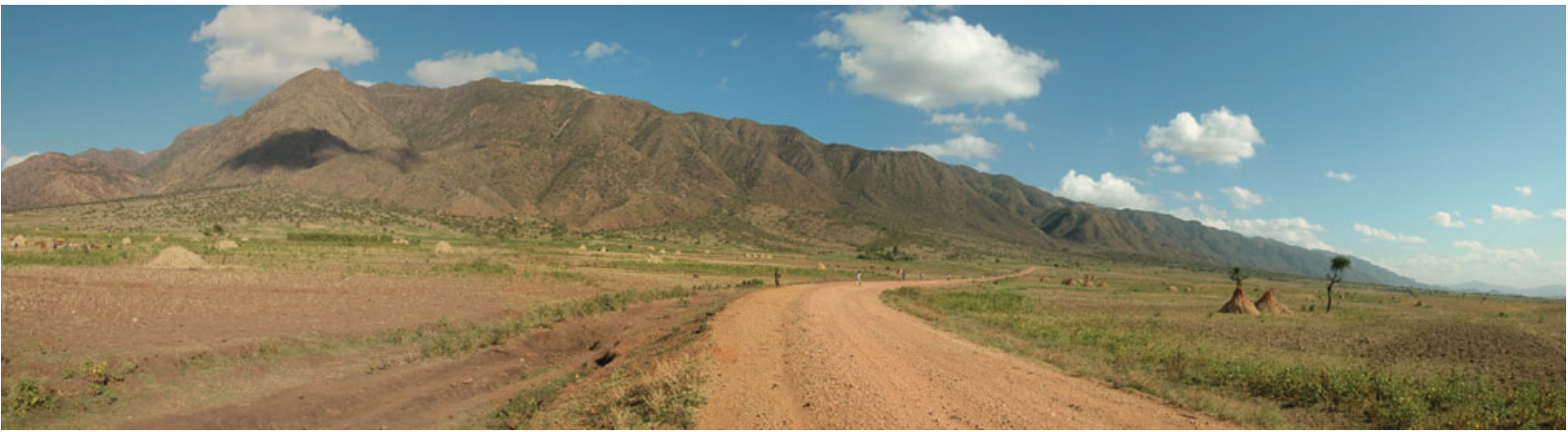

Fig. 15.5 Major normal fault bounding a marginal graben along the Ethiopian escarpment north of Dese (Photo M. Benvenuti)

\subsection{Rift Floor}

The floor of Afar has been shaped by $\sim 30$ million years of volcanic and tectonic processes that have led to the accumulation of voluminous volcanic rocks and to intense normal faulting. Although Oligocene to Early Miocene basalts belonging to the trap series are preserved in limited areas at the margins of the depression (e.g. Beyene and Abdelsalam 2005), the majority of volcanic rocks are Upper MioceneRecent in age and formed after the young rift subsided between the marginal faults. Volcanism is dominated by basaltic activity, whose most important manifestation is the Afar Stratoid Series, a $>55,000 \mathrm{~km}^{2}$-wide and $>1,500 \mathrm{~m}$-thick sequence consisting of basaltic lava flows and minor rhyolitic ignimbrites erupted in the Pliocene-Pleistocene ( $\sim 4-0.5 \mathrm{Ma})$ mainly from volcanic fissures (Barberi et al. 1975; Lahitte et al. 2003; Acocella 2010). Emplacement of this basaltic series was characterised by the highest eruption rates $\left(>5,000 \mathrm{~km}^{3} / \mathrm{Ma}\right)$ ever known for plate divergent margins and is instead more typical of a large igneous provinces (Acocella 2010). The most recent, Quaternary-Recent volcanoes are both composite stratovolcanoes, composed of interbedded rhyolites, ignimbrites, andesites and basalt flows (e.g. Dabbahu), and also shield volcanoes of mainly basalts (e.g. Erta Ale range). Both types of volcano are the source of observed fields of basaltic scoria cones, and fissure fed basaltic flows. The E-NE trending transverse volcanic alignments and trachytic-rhyolitic central volcanoes also characterise the Afar margins (e.g. Barberi and Varet 1977).

The significant volcanic activity is intimately related to extension-related faulting and magma intrusion, which since Quaternary-Recent times has been focused in axial magmatic segments (Figs. 15.2 and 15.6; e.g. Barberi and Varet 1977; Manighetti et al. 2001; Keir et al. 2013). The current faulting patterns are commonly quite complex and result from interaction between the subaerial Red Sea and Aden rifts and the northern termination of the Ethiopian rift (Figs. 15.1, 15.2 and 15.6). The Red Sea includes the Danakil depression in northern Afar and Manda-Hararo rift and Tendaho Graben in central Afar, whereas the subaerial Aden rift includes the Asal Ghoubbet and Manda-Inakir rifts to the east (Fig. 15.6; e.g. Keir et al. 2013). A series of relatively narrow grabens (such as the Dobi, Hanle and Gaddale grabens) in central Afar transfer strain from the Red Sea rift to the Gulf of Aden (e.g. Manighetti et al. 2001). The Ethiopian Rift includes the systems of NE trending grabens and volcanic alignments that result from Nubia-Somalia rifting south of the TendahoGoba'ad discontinuity (e.g. Tesfaye et al. 2003).

These different sectors of the Afar Depression (northern central and southern) show significant tectonic and structural differences, and hence are described separately in the following sections.

\subsection{Northern Afar}

The morphology of northern Afar is dominated by the Danakil Depression, a 200-220 km-long, relatively narrow (50-150 km-wide) basin bound to the west by a prominent fault escarpment forming $>2 \mathrm{~km}$ of relief at the western Afar margin and to the east by a less prominent series of faults forming a 500-1,000 m elevation rift margin against the Danakil microplate (Fig. 15.7). Despite being onland, the basin floor is generally $50-100 \mathrm{~m}$ below sea level with near-surface geology dominated by the a suite of marine evaporite deposits (e.g. calcite, gypsum, halite and sylvite). At least $2 \mathrm{~km}$ salt formed in the Danakil depression when it was a submarine arm of the Red Sea during the Miocene. The upper part of the series deposited during repeated marine incursions in the Pleistocene, when lava flows dammed the narrow neck between the northern end of the Danakil Horst and the western highlands and the sea water trapped in the depression soon evaporated. These incursions, the last of which occurred $\sim 30 \mathrm{ka}$ (e.g. Barberi and Varet 1970; Bonatti et al. 1971; Hutchinson and Engels 1972; Talbot 2008), left a classic pattern of marine reefs perched at altitudes of -30 to $+90 \mathrm{~m}$ along the former 


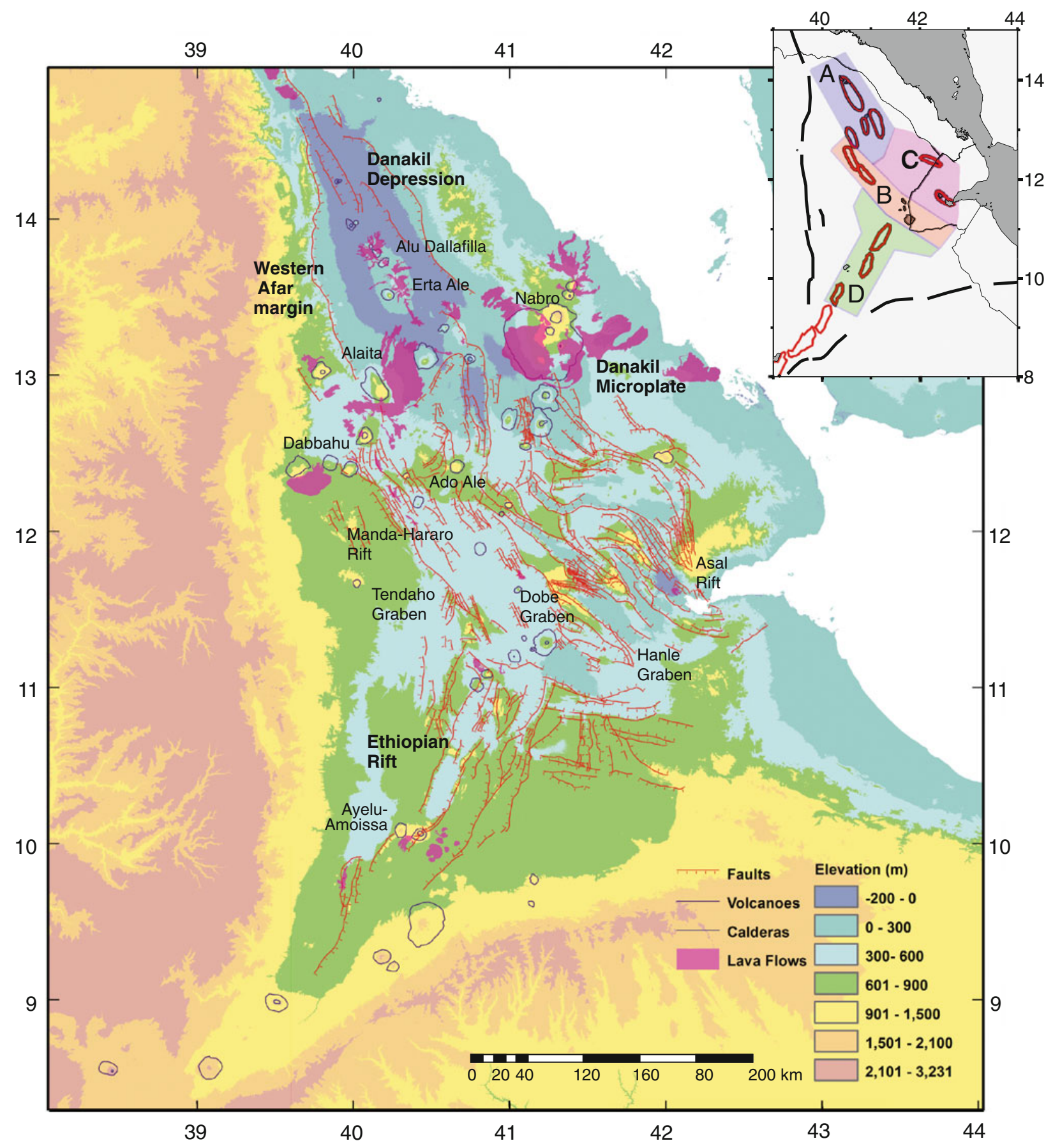

Fig. 15.6 Structural map of the Afar Depression (modified after Keir

The subaerial Red Sea rift is included in areas A (northern Afar) and B (western Afar). The subaerial Aden rift is included in region C (central, et al. 2013). Major Pliocene-recent faults affecting the rift floor are marked red. Recent basaltic lava flows are shaded light purple. The inset delineates the major rift system forming the Afar triple junction. eastern Afar), and the northern Main Ethiopian rift is area D (southern Afar)

shoreline around the margins of the depression. The basin also contains non-marine evaporites from ongoing evaporation of seasonal terminal saline lakes and the geothermal pools (Talbot 2008).
The axis of the Danakil depression is bisected by a linear, $\sim$ NNW striking, 10-20-km-wide axial volcanic range (Erta Ale range) which is the locus of ongoing volcanism and magmatism (e.g. Field et al. 2012; Pagli et al. 2012). This 
Fig. 15.7 Topography of Afar with major grabens and volcanic centres labelled. Upper right panel shows samples of topography on profiles $\mathrm{A}-\mathrm{A}^{\prime}$ across the Danakil depression and B-B' across central-eastern Afar. GT Gulf of Tadjoura

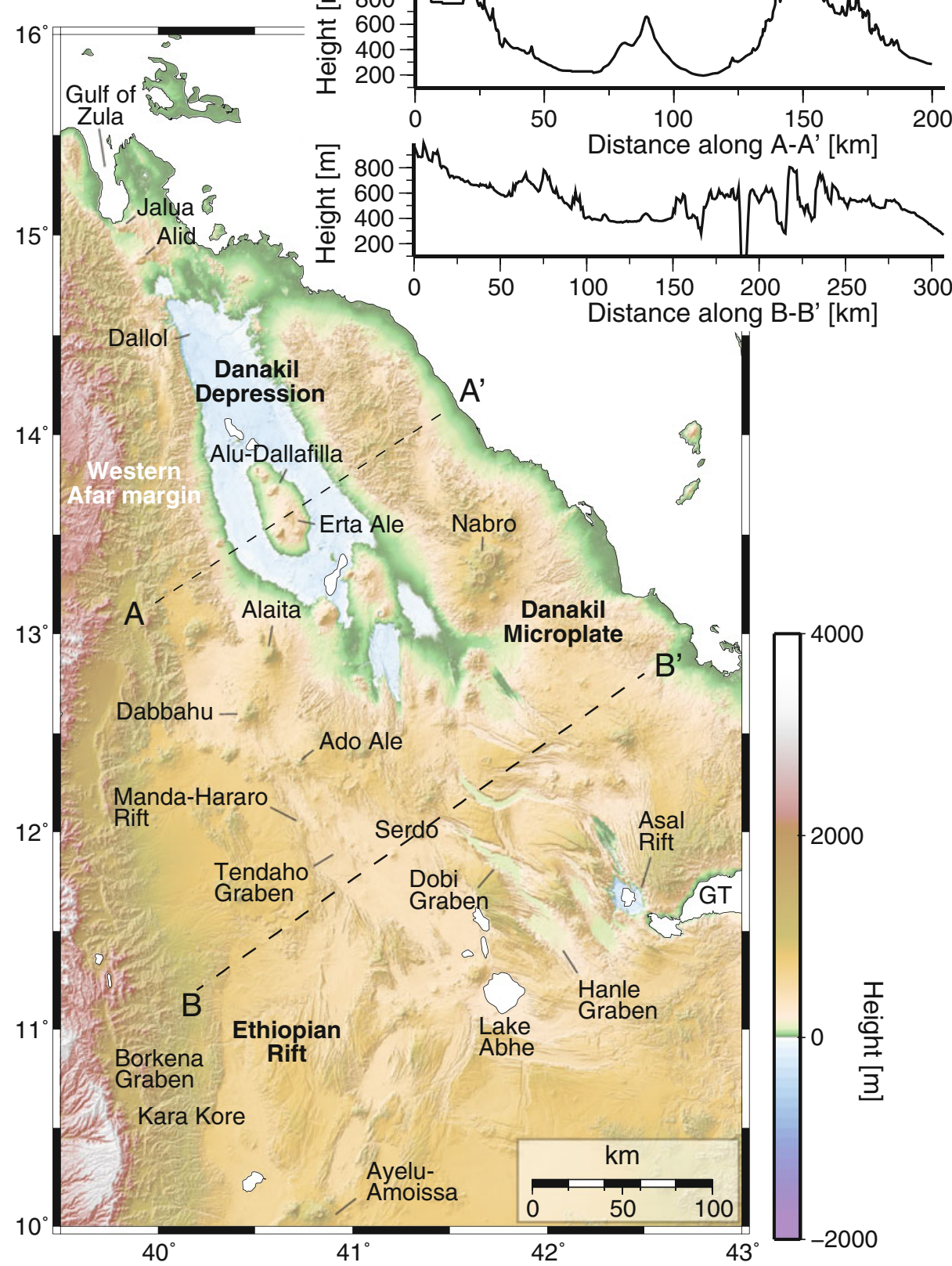

range, unlike elsewhere in Afar, does not form a heavily faulted graben, but a composite system of different volcanic centres with elevation of up $>500 \mathrm{~m}$ above sea level (Fig. 15.8; e.g. Barberi and Varet 1970). The volcanic rocks are largely dominated by Quaternary-Recent a'a and pahoehoe basalt flows (Thurmond et al. 2006), which create the classic shield volcano-like morphology with gentle slopes. A limited number of silicic centres create more prominent morphology, such as the steep-sided conical stratovolcano of Dalafilla that rises $300 \mathrm{~m}$ above surrounding lava fields SE of Alu volcano. The Erta Ale range is markedly elliptical in shape, reflecting a control on the pathways of magma migration and eruption exerted by axial, rift-parallel fissures (Fig. 15.8). Basalt flows are indeed fed from a combination of $\sim$ NNW-striking fissures and from edifices such as the $\sim$ NNW elongate main caldera hosting Erta Ale lava lake (e.g. Acocella 2006). The $\sim 1,700 \times 700 \mathrm{~m}$-wide, main caldera hosts a large northern crater and a smaller central crater (Fig. 15.9; Acocella 2006). The central crater hosts a small pit crater floored by the lava lake in which lava elevation changes through time. It reached its highest level in February 2010 when lava filled the pit crater; by November 2010, 

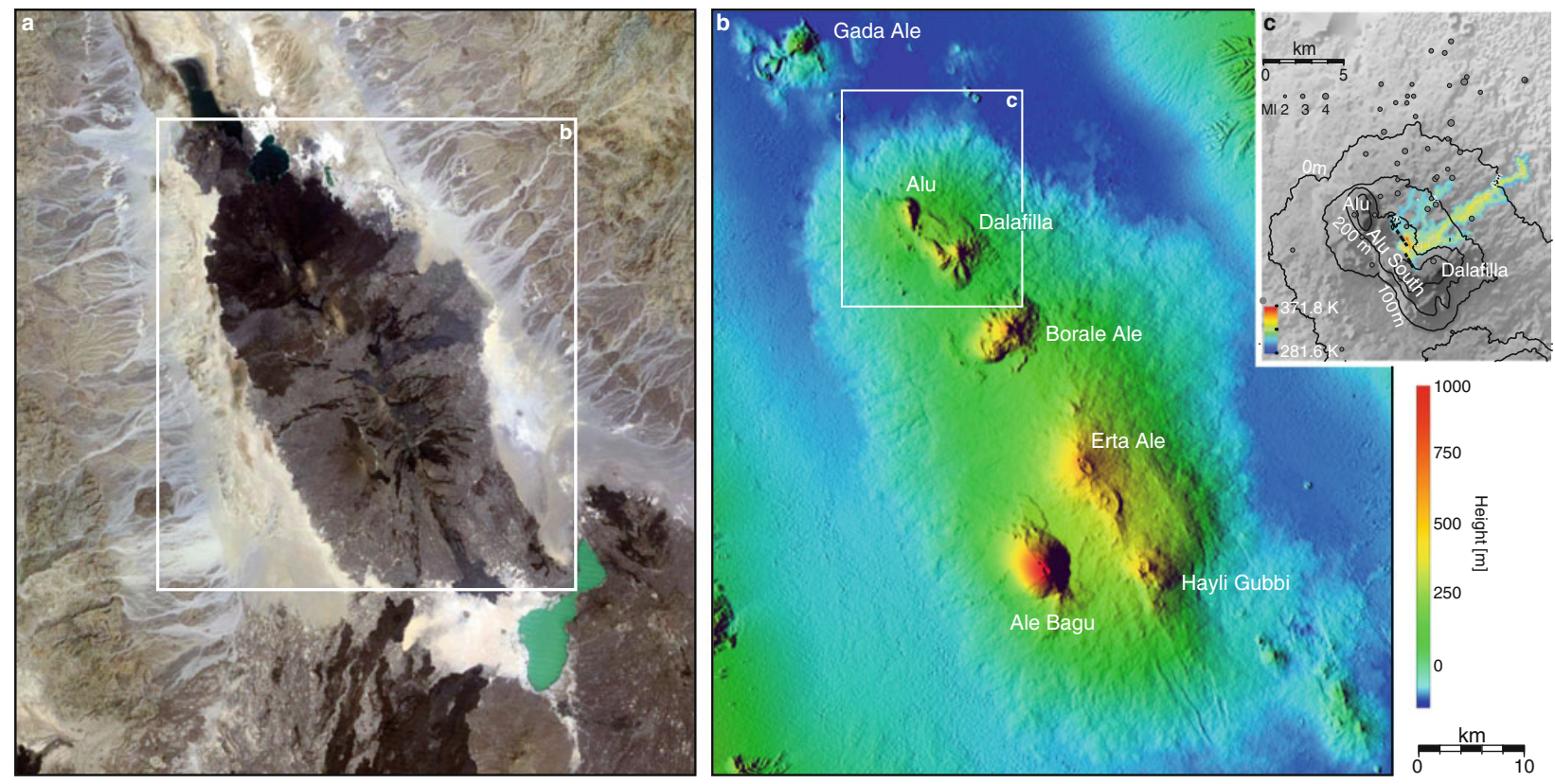

Fig. 15.8 Satellite image (Source Google Earth) (a) and digital elevation model (SRTM data) (b) of the Erta Ale range (c) The November 2008 eruption in the Alu-Dalafilla volcanic centre. Dashed

lines indicate the two en-echelon volcanic fissures, and the coloured area is the surface temperature of the erupted lava flow (from Pagli et al. 2012)

Fig. 15.9 Aerial view of the elongate caldera of the Erta Ale with the large northern and the smaller central pit craters (Photo E. Baker)

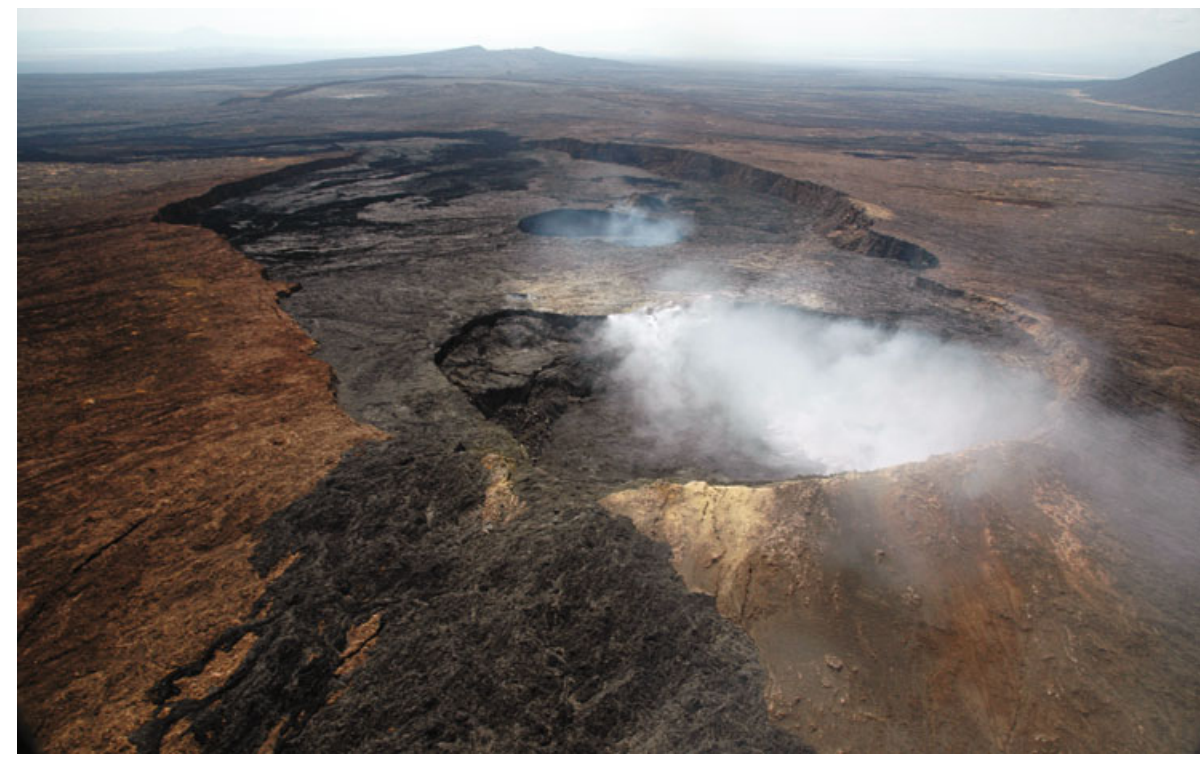

basalt overflowed into the main crater (Field et al. 2012). The larger northern crater also hosted a lava lake until early 1975. The lava lakes have been persistently active for at least 100 years (Waltham 2010). The geometry of the main caldera, the characteristics of erupted lavas as well as the modelling of the satellite data of recent eruptions all indicate that the volcanic activity in the Erta Ale range is likely fed from long-lived shallow (uppermost $2 \mathrm{~km}$ ) pockets of magma (e.g. Pagli et al. 2012; Keir et al. 2013). The importance of $\sim$ NNW-striking fissures in building the volcanic topography of the Erta Ale range is testified by the November 2008 eruption in the Alu-Dalafilla volcanic centre, where two enechelon fissures opened south-east of Alu and erupted lava that flowed towards the east and north of Dalafilla (Fig. 15.8; Pagli et al. 2012). InSAR data show that the eruption was accompanied by up to $\sim 1.9 \mathrm{~m}$ of subsidence at Alu. The deformation was caused by $\sim 1 \mathrm{~km}$-wide, $\sim 10 \mathrm{~km}$-long deflating sill beneath the volcanic system. 
Fig. 15.10 Multicoloured salt deposits, with small salt hornitos, at Dallol (Photo D. Keir)

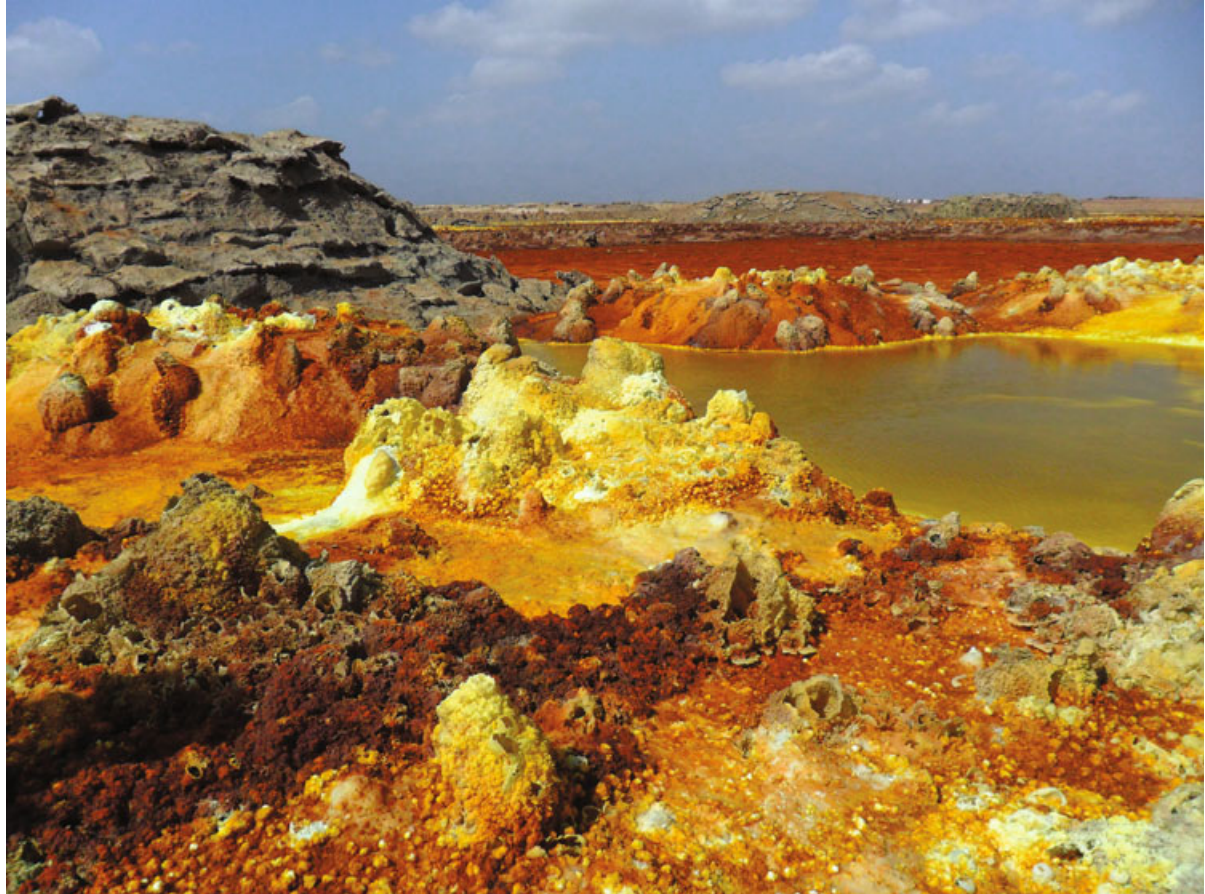

The axial lava flows of the Erta Ale range, which cover an order of magnitude more surface area than similar age basalts elsewhere in Afar (Bastow and Keir 2011), typically flow away into the lower lying, evaporite-rich basin, creating a basin stratigraphy of thinly interbedded basalts and evaporites (Talbot 2008), up to $\sim 5 \mathrm{~km}$-thick (e.g. Makris and Ginzburg 1987).

The Erta Ale range drops in elevation to the north with the Dallol volcanic centre, one of the lowest subaerial volcanic vents globally. Dallol is world renowned for multi-coloured salt and hydrothermal deposits, hot mineral springs, fumaroles and geysers (Fig. 15.10) which form as a consequence of a complex interaction of solution and recrystallisation processes driven by hydrothermal waters and rapid evaporation. Dallol has been the site of a significant phreatic eruption in 1926 , which created a crater $\sim 30 \mathrm{~m}$ in diameter (Siebert et al. 2010). Recently, satellite remote sensing and seismicity analysis captured the intrusion of $\sim 0.06 \mathrm{~km}^{3}$ dike accompanied by a $M_{w} 5.5$ earthquake and associated fault slip along the western flank of the rift during October 2004 (Nobile et al. 2012). The intrusion was fed by a previously unidentified shallow magma reservoir beneath Dallol. The volcano lacks volcanic rocks at the surface because they are covered by salt. The magmatic and tectonic activity also indicates that the Erta Ale range extends up to Dallol as a continuous and uniformly trending rift branch. Activity at the Alid and Jalua, north of Dallol, has not been reported but the spacing between magmatic centres suggests that the Erta Ale Ridge further extends to the Gulf of Zula on the Eritrean coast.

\subsubsection{Central Afar}

Central Afar is the complex region of mechanical interaction between the on-land southern continuation of the Red Sea Rift and the subaerial western continuation of the Aden Rift (e.g. Manighetti et al. 2001). The southern extent of the Red Sea Rift includes the Manda-Hararo Rift and the Tendaho Graben, in the west, whereas the Gulf of Aden extends into Afar in the Asal-Ghoubbet and Manda-Inakir rifts, in the east (Figs. 15.1 and 15.7). A complex architecture made of a series of relatively narrow, non-volcanic grabens (such as the Dobi, Hanle and Guma grabens) characterise the area between the Red Sea and Gulf of Aden systems, transferring extension between the two rift arms (e.g. Manighetti et al. 2001). These three different subsectors are discussed in the following sections.

\subsubsection{Manda-Hararo Rift and Tendaho Graben}

The Manda-Hararo Rift and the Tendaho Graben form a series of NNW-SSE striking, 30-60 km-wide, 80 km-long basins bordered by 200-300-m-high escarpments (Fig. 15.7). These generally lack a clear single border fault but are characterised by numerous closely spaced relatively small-offset faults that displace the Stratoid Series and define several rigid blocks tilted toward the rift axis (Figs. 15.11 and 15.12; e.g. Acocella et al. 2008). This inward-dipping Stratoid blocks arranged in a domino configuration inside the margins result in an overall syncline-like structure of the basins (e.g. the central part of the Tendaho Graben; Acocella 
Fig. 15.11 Structure and mechanism of formation of the Tendaho Graben (modified from Acocella 2010). a Structure of the central part of the graben. b above topographic section along the profile indicated in $\mathbf{a}$; below simplified structure (not to scale) of the Tendaho Graben in cross section; double arrows report extent of block domains with similar tilt. Note the domino-like structures, with blocks characterised by a uniform tilt angle separated by faults. c Mechanism of formation of the graben as a consequence of repeated magma withdrawal from a rift-parallel elongated reservoir
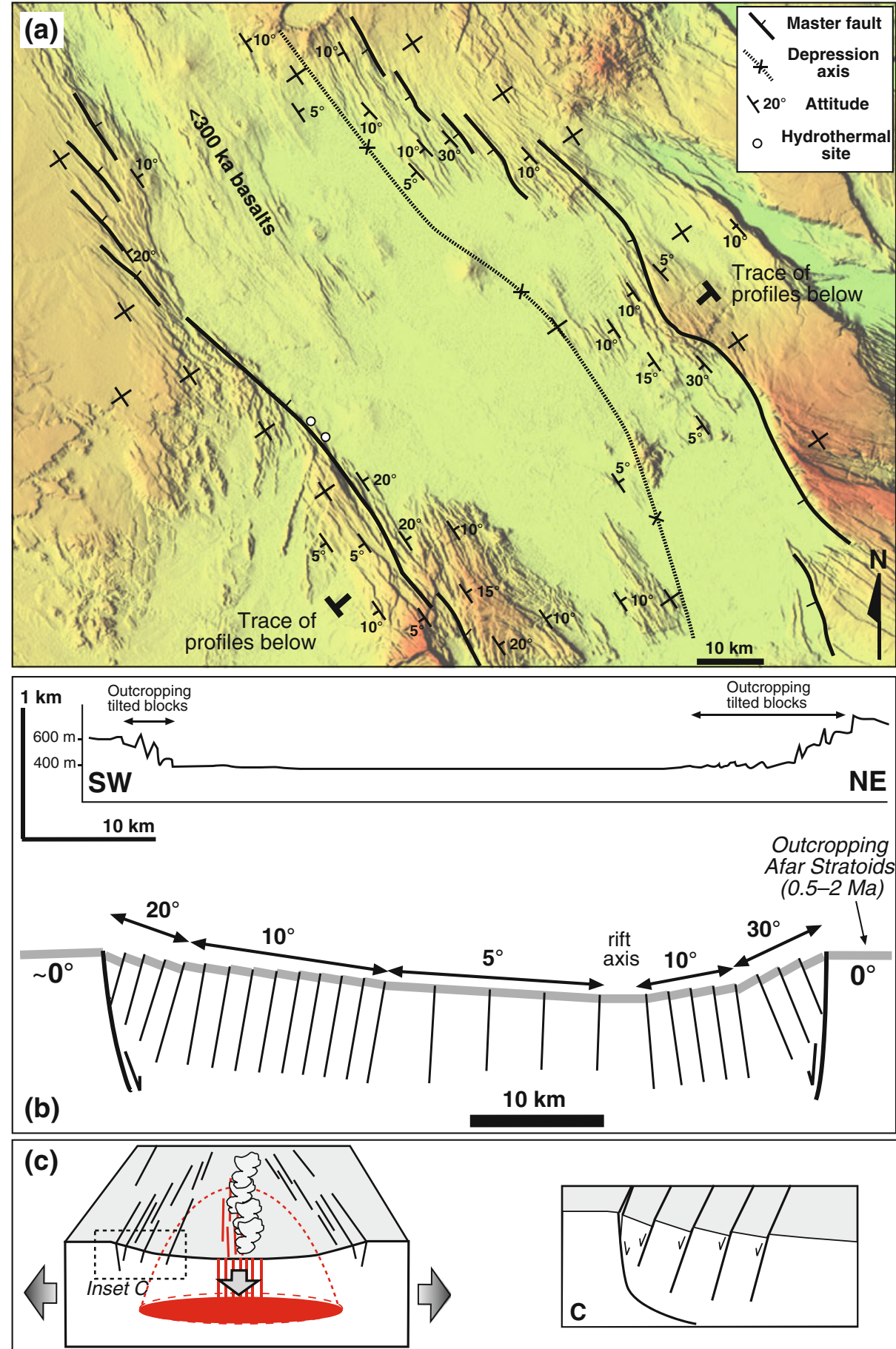

et al. 2008), a geometry that has been related to rift collapse induced by magma withdrawal during the emplacement of the Stratoid sequence (Fig. 15.11; Acocella 2010). The basins are filled with $>1 \mathrm{~km}$ of lacustrine and fluvial deposits as well as by Quaternary-Recent volcanic rocks, the distribution and age of which suggest that faulting and volcanism have progressively localised through the Quaternary to a $\sim 10 \mathrm{~km}-$ wide central axis where the youngest ( $0-0.2$ Ma old) fissural basalts crop out (Lahitte et al. 2003; Acocella et al. 2008; Acocella 2010). At the southern tip of the Tendaho Graben, Lake Abhe is characterised by hundreds of travertine towers, giving rise to several linear chains of travertine chimneys. Each tower is up to $60 \mathrm{~m}$ tall, formed by geothermal activity (e.g. Waltham 2010; Hussein et al. 2013). 
Fig. 15.12 The eastern side of Tendaho Graben (Photo D. Keir)

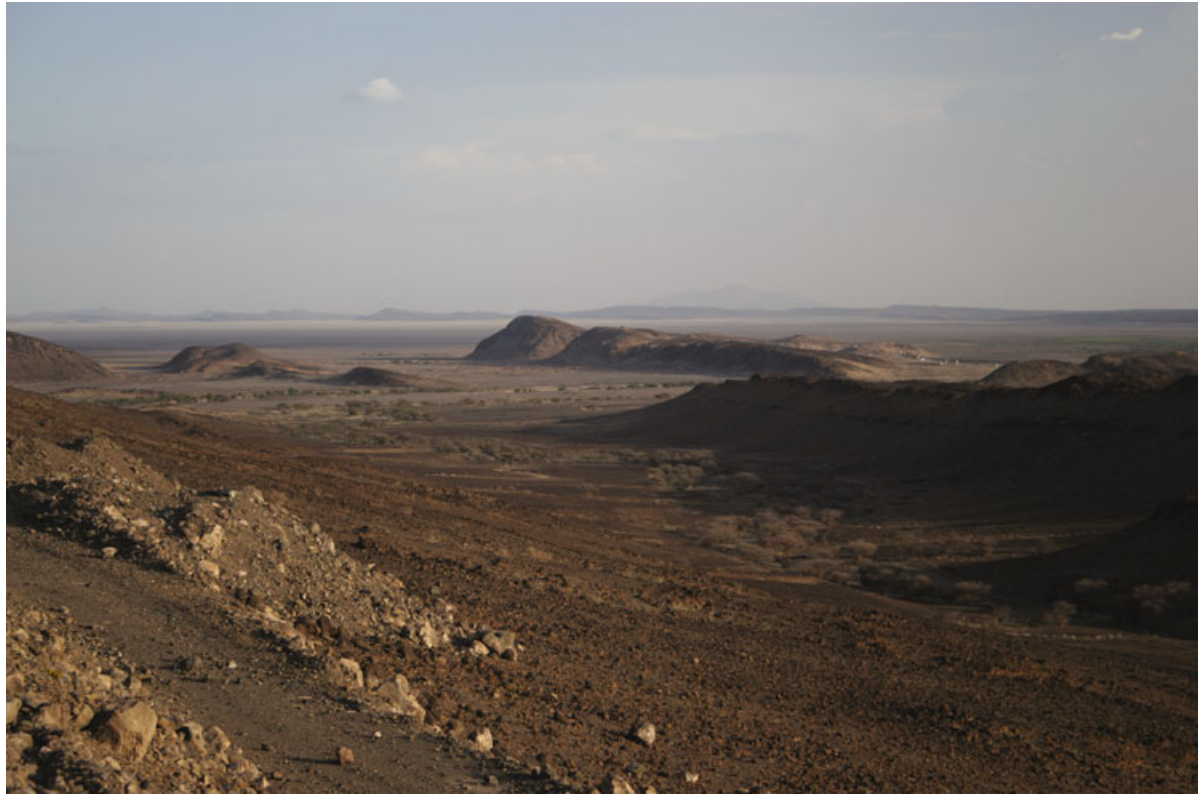

The northern part of the Manda-Hararo rift is the $\sim 60$-km-long and $\sim 15$-km-wide Dabbahu volcanic segment, which has been the locus of a major volcano-tectonic episode during 2005-2010 (e.g. Wright et al. 2006; Rowland et al. 2007; Grandin et al. 2009; Ebinger et al. 2010). The event was characterised by the emplacement of a $\sim 60 \mathrm{~km}$-long, up to 10 -m-thick basaltic dike into the upper $10 \mathrm{~km}$ of the crust beneath the magmatic segment during September 2005 (Fig. 15.13), accompanied by a minor eruption of pumice and ash on 26 September from the Da'Ure vent near Dabbahu (Fig. 15.14; e.g. Wright et al. 2006). Dike intrusion was accompanied by near-symmetrical rift perpendicular opening of up to $8 \mathrm{~m}$, with the flanks of the rift uplifted by up to $2 \mathrm{~m}$, and a $2-3-\mathrm{km}$-wide graben subsiding by $2-3 \mathrm{~m}$ (Figs. 15.14 and 15.15; e.g. Wright et al. 2006; Ayele et al. 2007; Grandin et al. 2009). Slip on individual normal faults was up to $3 \mathrm{~m}$, with magnitude of seismic events peaking up to magnitude $M_{L}=5.6$ (Ayele et al. 2007; Rowland et al. 2007). From June 2006 to May 2010, the initial dike has been followed by a sequence of 13 smaller dikes typically $1-3 \mathrm{~m}$ thick and 10-15 km long (e.g. Ebinger et al. 2010; Wright et al. 2012). Three of these dikes reached the surface as basaltic fissural eruptions, although the total erupted volume is a small fraction of that intruded into the crust (Ferguson et al. 2010). Geophysical data of this suggest that the majority of the intrusions were fed laterally from a $\sim 10$-km-deep magma reservoir beneath the Ado'Ale volcanic complex located at the centre of the segment (Ayele et al. 2009; Grandin et al. 2009). These episodic events of normal faulting and axial graben subsidence induced by lateral dike intrusion from a segment-centred magma reservoir are modulated by cyclic variations in magma supply (Medynski et al. 2013) and function to maintain the morphology of volcanic segments (e.g. Wright et al. 2006, 2012; Keir et al. 2009; Ebinger et al. 2010; Grandin et al. 2010).

\subsubsection{Asal-Ghoubbet and Manda-Inakir Rifts}

The eastern-north-eastern edge of central Afar is characterised by a narrow zone of dense faulting that includes the two NW-SE trending volcanic rifts of Asal-Ghoubbet, to the south, and Manda-Inakir, to the north (Fig. 15.16; e.g. Manighetti et al. 1998, 2001). These two rifts formed in the last $1 \mathrm{Ma}$, when extension in the Gulf of Aden localised to axial volcanic segments breaching the Danakil Block from the Ali-Sabieh Block and proceeding along the Gulf of Tadjoura into the Afar Depression (e.g. Manighetti et al. 1998). The $\sim 40-\mathrm{km}$-long, 15-km-wide Asal-Ghoubbet is the first segment of the Aden ridge to rise significantly above the sea level. Steep, inward dipping normal faults delimit the 300-800-m-deep basin, which is subdivided in at least two disconnected, parallel subrifts; the rift floor is cut by dense arrays of open fissures roughly parallel to the normal faults (Fig. 15.17; Manighetti et al. 1998). Both fissures and normal faults often display sharp and youthful morphology, with steep walls in fine white silts, suggesting development during earthquakes in the last century (Manighetti et al. 1998). Deformation recorded by means of geodetical and geophysical data also shows the ongoing activity of the majority of the faults (e.g. Doubre et al. 2007). Notably, the northwestern subrift has faults with sharper and fresher scarps, and wider and denser fissures; this suggests that this subrift is younger than the one to the south-east and that deformation has migrated to the north-west with time (Manighetti et al. 1998). 

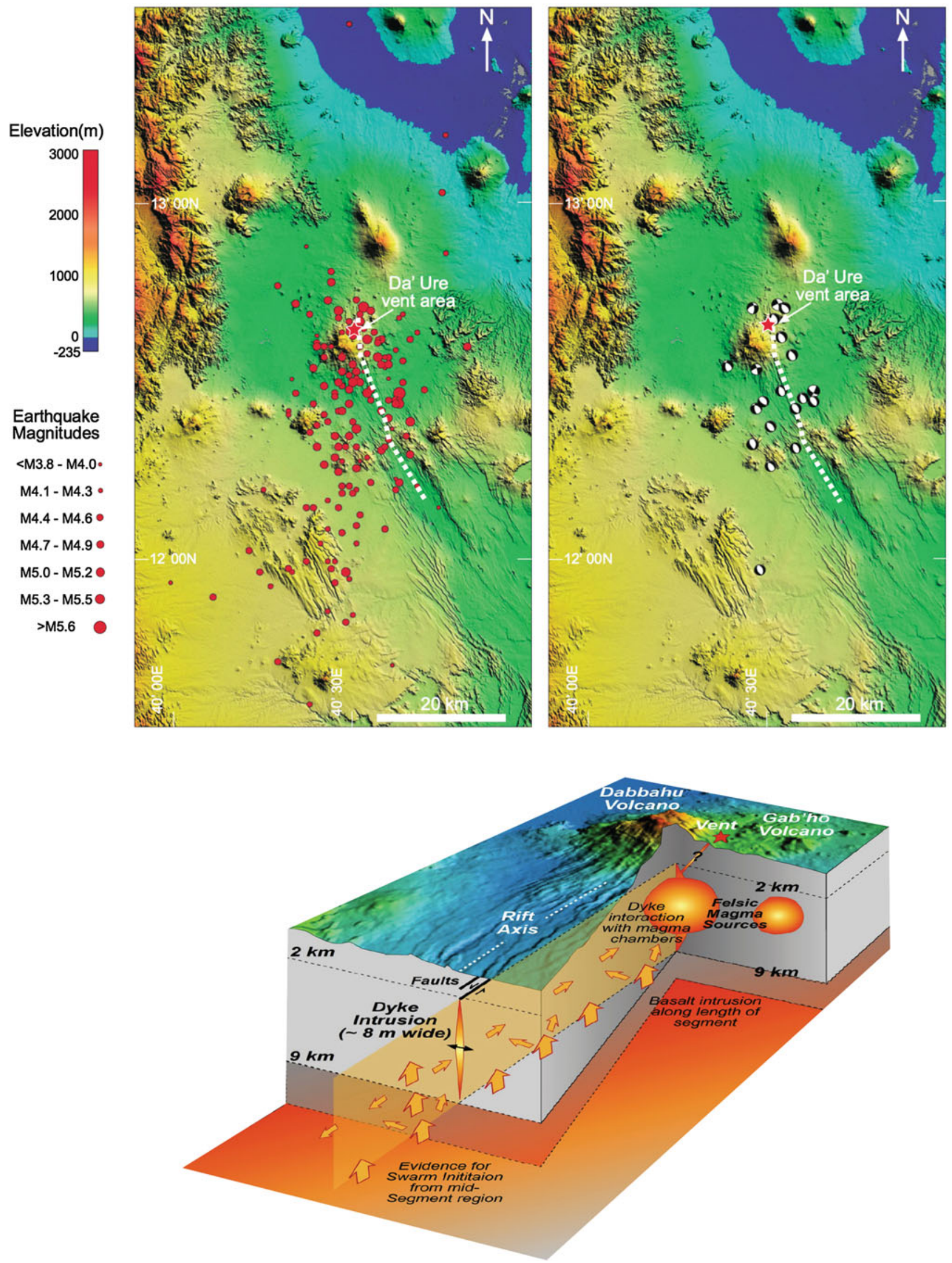
Fig. 15.13 The top left and right panels, respectively, show earthquake locations reported by the National Earthquake Information Center (NEIC) and focal mechanism reported by the Global Centoid Moment Tensor Catalog, for the September 2005 Dabbahu rifting episode. Normal fault earthquakes were primarily located along the Dabbahu segment. The lower panel is a cartoon sketch illustrating that the fault slip causing graben subsidence is a relatively shallow phenomenon occurring mainly in the upper few kilometres of the Earth. The fault slip is induced by magma intrusion sourced from upper crustal magma chambers such as Dabbahu, Gabho and the Ado'Ale volcanic complex (not shown). Magma intrusion occured mainly at 2 $10 \mathrm{~km}$ depth beneath the rift
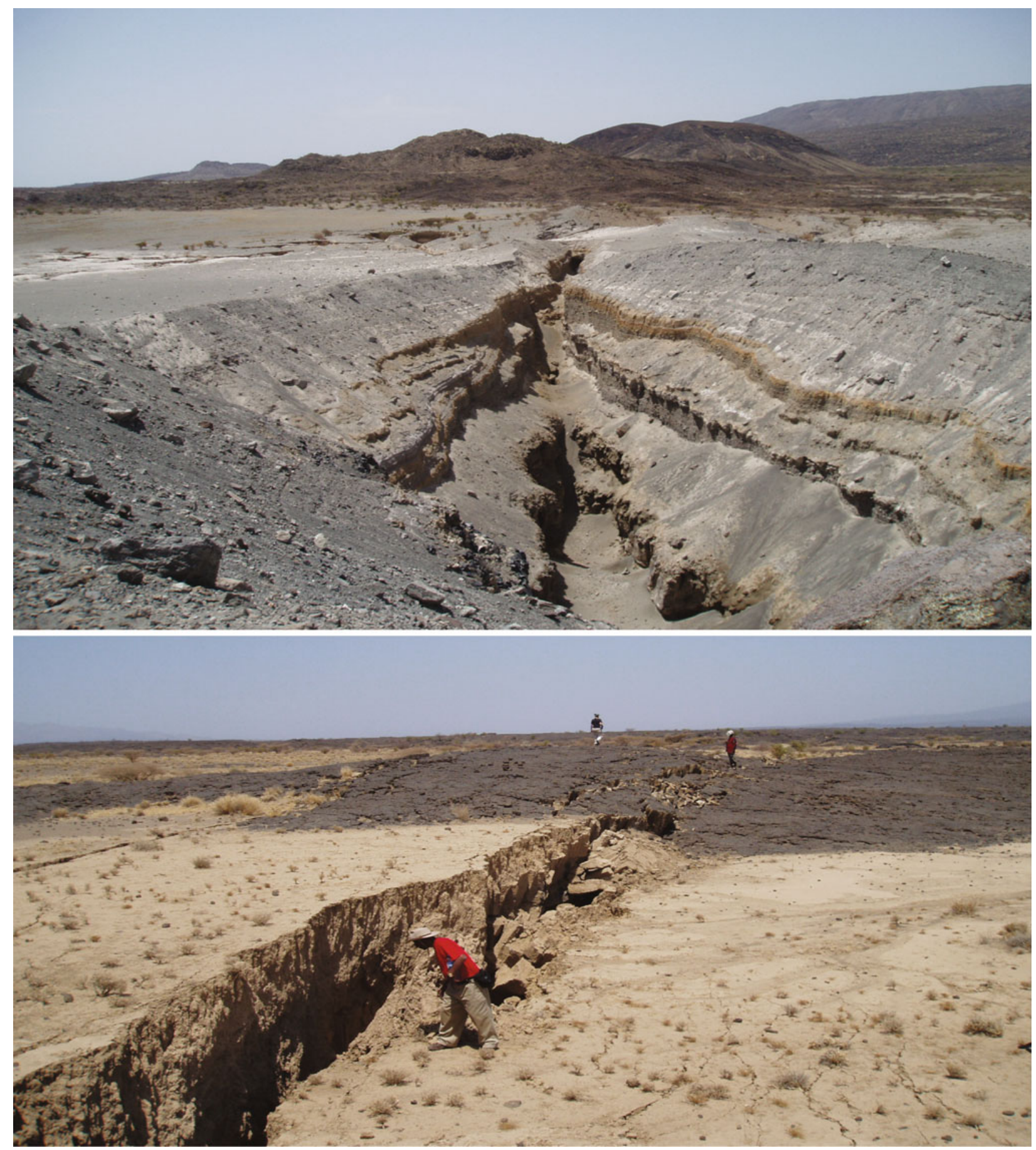

Fig. 15.14 Top The Da'Ure vent near Dabbahu formed during a minor eruption of pumice and ash on 26 September 2005 . Bottom Normal fault formed during the volcano-tectonic event (Photos E. Baker) 
Fig. 15.15 Vertical and horizontal displacements (left and central panels) following the 2005 Dabbahu rifting episode and traces of the faults that were activated during the event (right panel). Modified after Grandin et al. (2009)

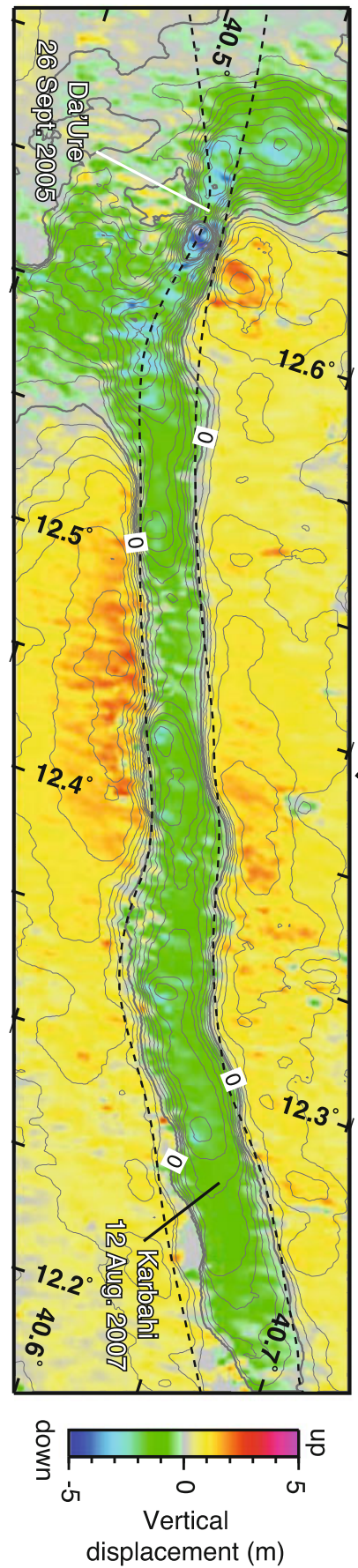

displacement (m)
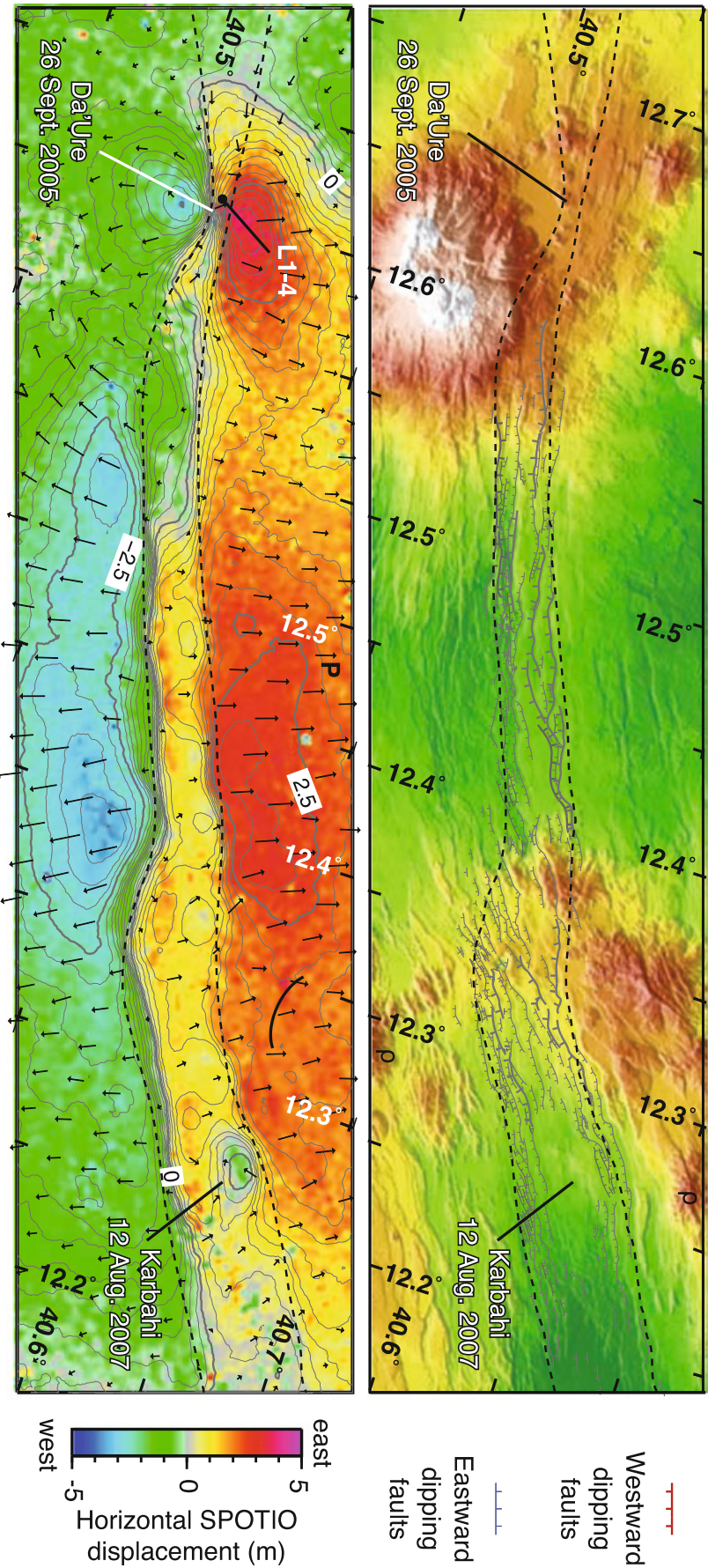

Active volcano-tectonic activity in the area is testified by a rifting event in November 1978, characterised by a major earthquake $\left(M_{b}=5.3\right)$ near the rift axis close to the coast of the Ghoubbet Bay and a seismic swarm that lasted for 2 months (Ruegg et al. 1979). This earthquake produced $\sim 2 \mathrm{~m}$ of extension and up to $\sim 70 \mathrm{~cm}$ subsidence, accommodated by the opening of several fissures and the reactivation of normal fault scarps on the rift axis; slip on individual faults varied between 0.15 and $0.5 \mathrm{~m}$ inside a 3-km-wide zone along $10 \mathrm{~km}$ of the exposed area between Goubhet and Asal (Ruegg et al. 1979). This deformation was associated with basalt flows from numerous fissures and vents at the newly formed volcanic centre of Ardoukôba, located north-west of a large volcano (Fieale) in the centre of the Asal-Goubhet rift (Figs. 15.16 and 15.17). Mechanical modelling of the deformation suggests that the rifting episode 


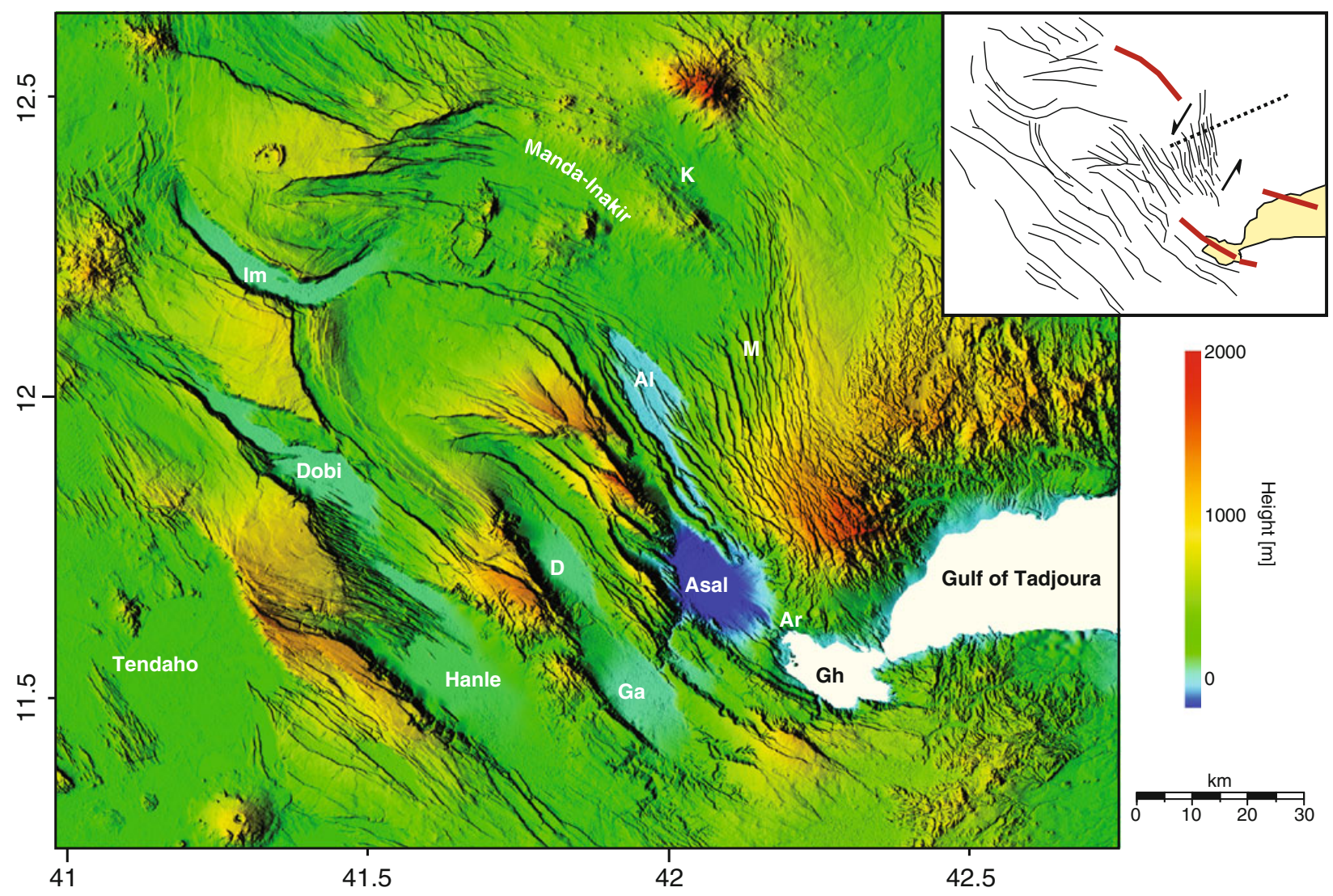

Fig. 15.16 Digital Elevation Model (SRTM data) of easternmost central Afar. Inset shows a tectonic sketch, with indicated the active volcano-tectonic rift segments of Tadjoura, Asal-Goubhet and Manda Inakir (after Manighetti et al. 2001). Normal faults are indicated in black; arrows indicate the relative motion of the Mak'arrasou transfer zone between the Asal-Goubhet and Manda Inakir segments; black dashed line indicates the trace of the profile shown in Fig. 15.18. Al Alol; Ar Ardoukoba; $D$ Der'Ela; $G a$ Gaddale; $G h$ Goubhet; $K$ Kammourta; Im Immino; $M$ Mak'arrasou oblique transfer zone resulted from the opening of two 4- to 8-km-long axial dikes at 4-5 km depth (Tarantola et al. 1979). Following the 1978 event, dike inflation continued up to 1985 , accompanied by seismicity and fault activity that continues today (Cattin et al. 2005; Doubre et al. 2007). Overall, the style of volcanotectonic activity in the Asal-Goubhet rift suggests that its structure and morphology were likely created during episodes of lateral migration of magma along rift-parallel shallow dikes, fed by a magma chamber beneath the rift centre (e.g. Doubre et al. 2007), as is observed at Dabbahu.

To the north-north-west, the Asal-Ghoubbet rift is connected to the Manda-Inakir rift, a volcanic range characterised by Pleistocene-Holocene lava flows and associated normal faults (Fig. 15.16; Manighetti et al. 1998). Connection between the two rifts occurs through the Mak'arrasou oblique transfer zone, which is composed of a network of closely spaced extensional faults and tilted blocks dipping towards Afar and giving rise to a large-scale flexure (Fig. 15.18; Le Gall et al. 2011). Volcanic products in the Manda-Inakir rift are associated to two large shield volcanoes: Inakir to the south-east, an elongated NW trending dome with numerous parasitic spatter cones, and Manda, with more easterly trend and hosting the most recent lavas (Fig. 15.19; Manighetti et al. 1998). Swarms of normal faults are mostly localised north-east of the volcanic zone and form three parallel subrifts; their topography is more attenuated than in the Asal-Goubhet rift suggesting a younger development of faulting in the area (Manighetti et al. 1998). Some of the bounding normal faults exhibit extremely fresh morphology, with light-coloured scarplets, suggesting they have likely ruptured in the last few hundred years (Tapponnier et al. 1990). As in the Asal-Goubhet rift, several open fissures (commonly more than $10 \mathrm{~m}$ deep and several meters wide) affect the rift floor. These fissures are often sharp and steep and with very fresh morphology suggesting very recent activity; some of them cut Late Pleistocene basalt flows in the rift floor. Most of youngest faults and fissures are concentrated in the north-western subrift, suggesting that-likewise the Asal-Goubhet rift - deformation propagated from southeast to north-west (Manighetti et al. 1998). Historical 


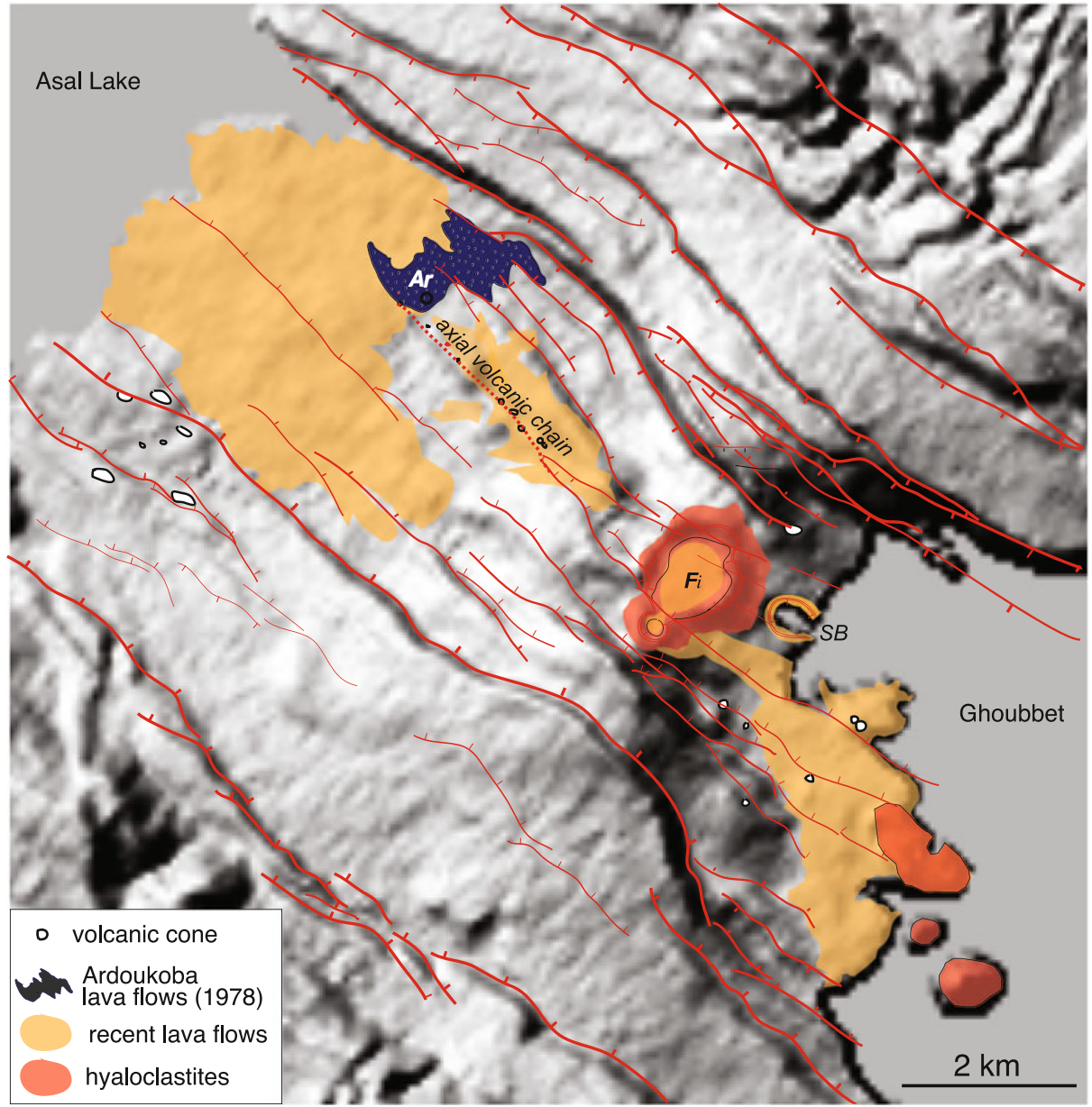

Fig. 15.17 Tectonic and simplified geological map of the subaerial section of the Asal-Goubhet Rift superimposed onto a SRTM digital elevation model (after Doubre et al. 2007). Ar Ardoukoba; Fi Fieale caldera; SB Shark Bay caldera

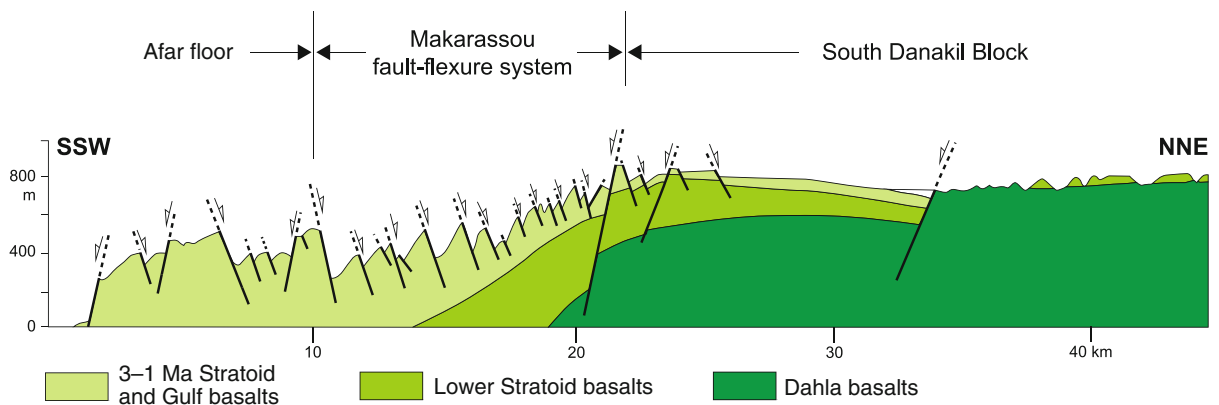

Fig. 15.18 Structural cross section of the central part of the Makarassou fault system, at the eastern margin of the Afar Depression (after Le Gall et al. 2011). Vertical exaggeration $=4$. Trace of the

volcanic activity was reported in the area, with the last eruption occurring in 1928 or 1929 at the south-eastern end of the Manda-Inakir rift and producing the Kammourta cinder cone and a lava flow (Audin et al. 1990). profile shown in Fig. 15.16. Note the network of closely spaced extensional faults and tilted blocks giving rise to hogback-like structures and a large-scale flexure towards Afar

\subsubsection{Basins Between the Red Sea and Gulf of Aden Systems}

In the central portion of Afar, between the Gulf of Aden and Red Sea systems, deformation is spread over an area 


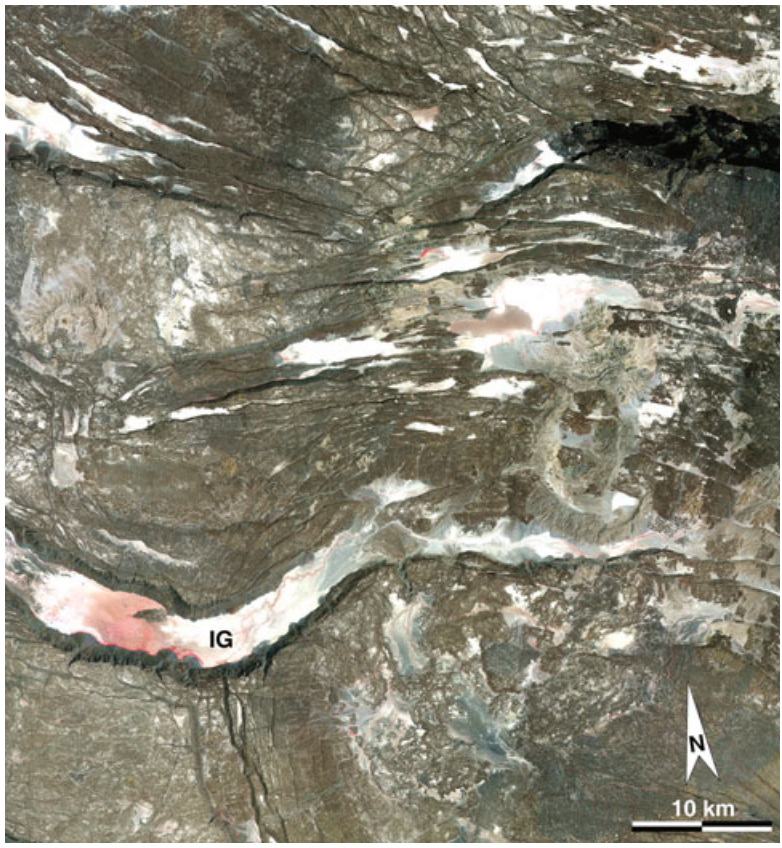

Fig. 15.19 NASA Earth Observatory image of central Afar. The black area close to the top right corner is the recent basaltic lava field of the Manda volcanic centre. The narrow, curved depression in the centre of the image is the Immino graben (IG)

$\sim 120 \times 100 \mathrm{~km}$ (Figs. 15.16 and 15.19; e.g. Manighetti et al. 2001). This region is completely overlain by the thick series of the Stratoid basalts and characterised by a lack of younger volcanism. South of $\sim 12^{\circ} \mathrm{N}$, the Stratoid series is dissected by a series of NW trending major normal fault systems with high $(100-1,000 \mathrm{~m})$, steep $\left(>70^{\circ}\right)$ cumulative escarpments, and numerous smaller, subparallel normal faults in between. The major border faults trend NW and define 10-20-km-wide and 30-50-km-long subparallel basins (e.g. Dobi, Hanle, Der'Ela, Gaddale), with intervening narrow horst blocks, so that the whole area is characterised by an overall horst-andgraben morphology (Figs. 15.16 and 15.20). North of latitude $\sim 12^{\circ} \mathrm{N}$, deformation becomes more complex, being characterised by a network of major crosscutting active faults giving rise to curvilinear narrow grabens (e.g. Immino graben; Fig. 15.19). The basin is filled by up to $>1,500$-m-thick sediments, mostly Quaternary-Recent lacustrine deposits and alluvial fans deposited during wet periods at the base of large fault escarpments (Gasse 1991). Most of the normal faults affecting the area are characterised by a fresh morphology, with a scarplet at the base of the cumulative escarpment offsetting Late Quaternary alluvial fans, thus attesting their recent/ongoing activity (Fig. 15.21; Manighetti et al. 2001). Several destructive earthquakes with recorded surface deformation have affected the area. A major earthquake affected the area of Serdo, between the Tendaho and Dobi grabens, in March-April 1969 (magnitude up to $M_{s}=6.3$ ), with several reported surface breaks and oblique, left-lateral faulting with displacement up to $\sim 75 \mathrm{~cm}$ (Gouin 1979). Another series of destructive earthquakes, ten with $5.5 \leq$ $M_{s} \leq 6.3$, struck the Dobi graben on August 20-21 1989, rupturing both boundary and inner floor faults over an area about $45 \mathrm{~km}$ long and $15 \mathrm{~km}$ wide (e.g. Jacques et al. 2011). Numerous surface breaks with complex geometry, including fresh scarplets with vertical throws up to $30-\mathrm{cm}$-high and open fissures up to $30 \mathrm{~cm}$ wide, were associated to the events (Fig. 15.22). The two largest shocks $\left(M_{s}=6.2\right.$ and 6.3) ruptured the southern segments of the south-western bounding fault of the Dobi graben; a dozen other faults also slipped along the edges of, and inside, the graben (Jacques et al. 2011).

Overall, the complex, distributed deformation affecting the area between the Gulf of Aden and Red Sea system results from the overlap without direct connection of the two major rift arms, which has been suggested to induce a bookshelf faulting mechanism in which small rigid blocks rotate about vertical axis along rift-parallel faults that slip with a component of left-lateral motion (Fig. 15.23; e.g. Tapponnier et al. 1990). The proposed block rotations were also previously cited as evidence that extension in Afar is controlled by the anticlockwise rotation of the Danakil block, a model called the Danakil crank-arm model (Souriot and Brun 1992). Recent geophysical data have been used to test these models with GPS data confirming that the Danakil block does currently rotate anticlockwise (McClusky et al. 2010). However, the large component of strike slip motion on the faults in central Afar is unclear since the majority of earthquake focal mechanisms show normal faulting (e.g. Keir et al. 2013), and the deformation field constrained using InSAR and GPS also shows rift perpendicular extension in the overlapping/en-echelon basins in central Afar with no major shear component of motion (Pagli et al. 2014).

\subsubsection{Southern Afar}

South of the Tendaho-Goba'ad discontinuity in the East African Rift, the morphology of the rift floor of the MER is dominated by the presence of $\sim 30 \mathrm{~km}$-wide, $\sim 60 \mathrm{~km}$-long en-echelon axial volcanic segments (Figs. 15.2 and 15.24). These are characterised by strong association of active and recent volcanoes, aligned monogenetic cones and fissures, and numerous normal faults striking roughly perpendicular to the direction of extension (e.g. Keir et al. 2013). The faults of the axial volcanic segments are normally short, closely spaced and display relatively small throws $(<100 \mathrm{~m})$, giving rise in places to a graben-in-graben morphology (Fig. 15.24) (Soliva and Schulz (2008). These faults are characterised by steep (subvertical) scarps and are commonly en-echelon and linear or curved in plan view over 
Fig. 15.20 Top panel The dry alluvial plains bounded by major normal fault escarpments of the Dobi graben. Inset shows a satellite image of the region. Bottom panel A salt pan in the Dobi Graben, where locals pump water onto the flat basin floor and then wait for it to evaporate. Major boundary faults in the background (Photos E. Baker and D. Keir)
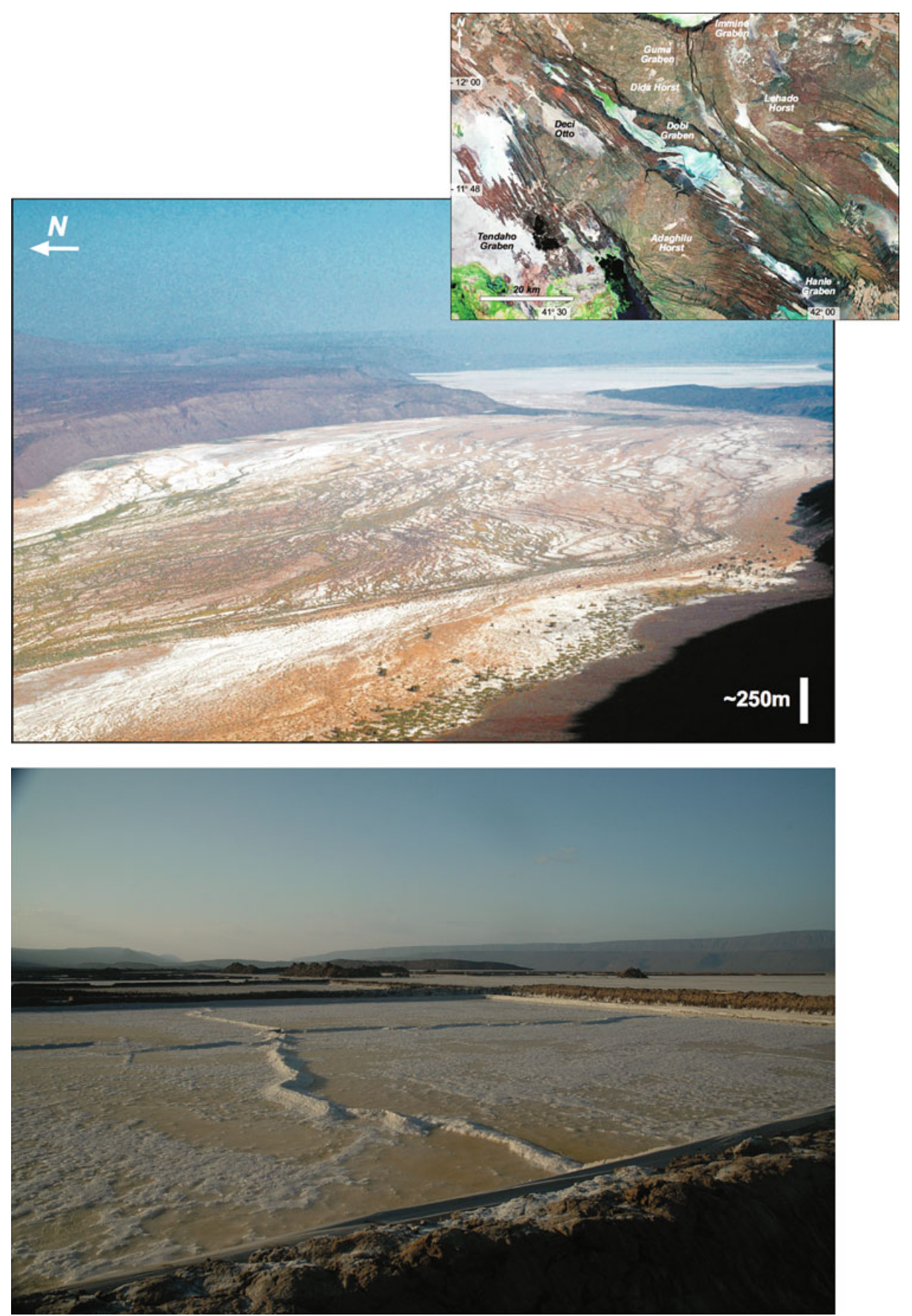

distances of up to a few tens of kilometres, thus delimiting several fault-bounded blocks. Associated with the faults are open fissures with or without vertical displacement, splay patterns and complex rhomb-shaped structures (e.g. Mohr 1987; Boccaletti et al. 1998; Williams et al. 2004). Structural and geomorphological analyses suggest a migration of deformation toward the axis of the volcanic segments, with inner normal faults displacing recent basalt flows erupted from rift-parallel fissures and eroded more external faults
(Hayward and Ebinger 1996). The axial basins are filled with both volcanic products and sequences of Pliocene-Recent alluvial and lacustrine sediments, with rivers eroding the uplifted fault footwalls and producing depositional fans in the basins (Hayward and Ebinger 1996).

The dense fault swarms developed in the last $2 \mathrm{Ma}$ (e.g. Ebinger and Casey 2001) and geodetic data support that they accommodate $\sim 80 \%$ of the present-day strain (Bilham et al. 1999). Gravity and seismic imaging show extensive 


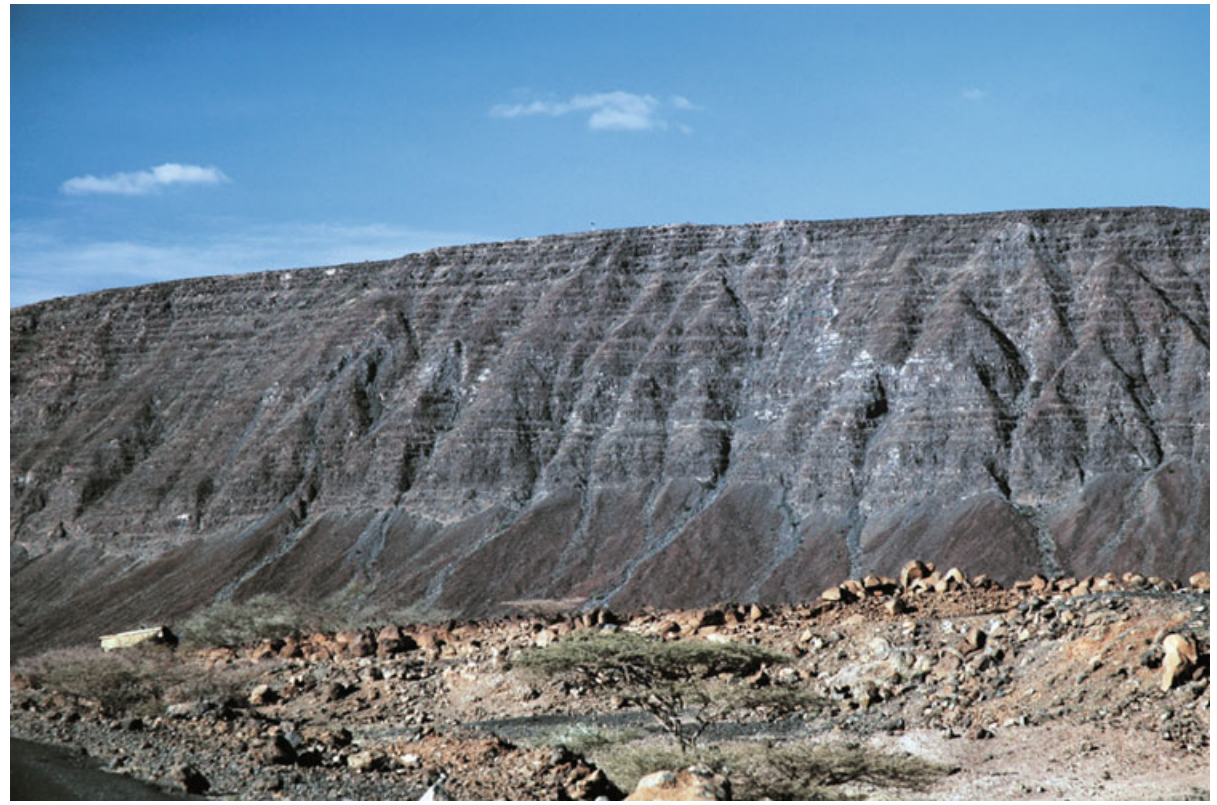

Fig. 15.21 A major boundary fault of the Dobi graben displacing the Afar Stratoid series, with the thick succession of basalt flows visible on the fault footwall (Photo E. Baker). Note the presence of a fresh, light-coloured scarplet at the base of the cumulative escarpment

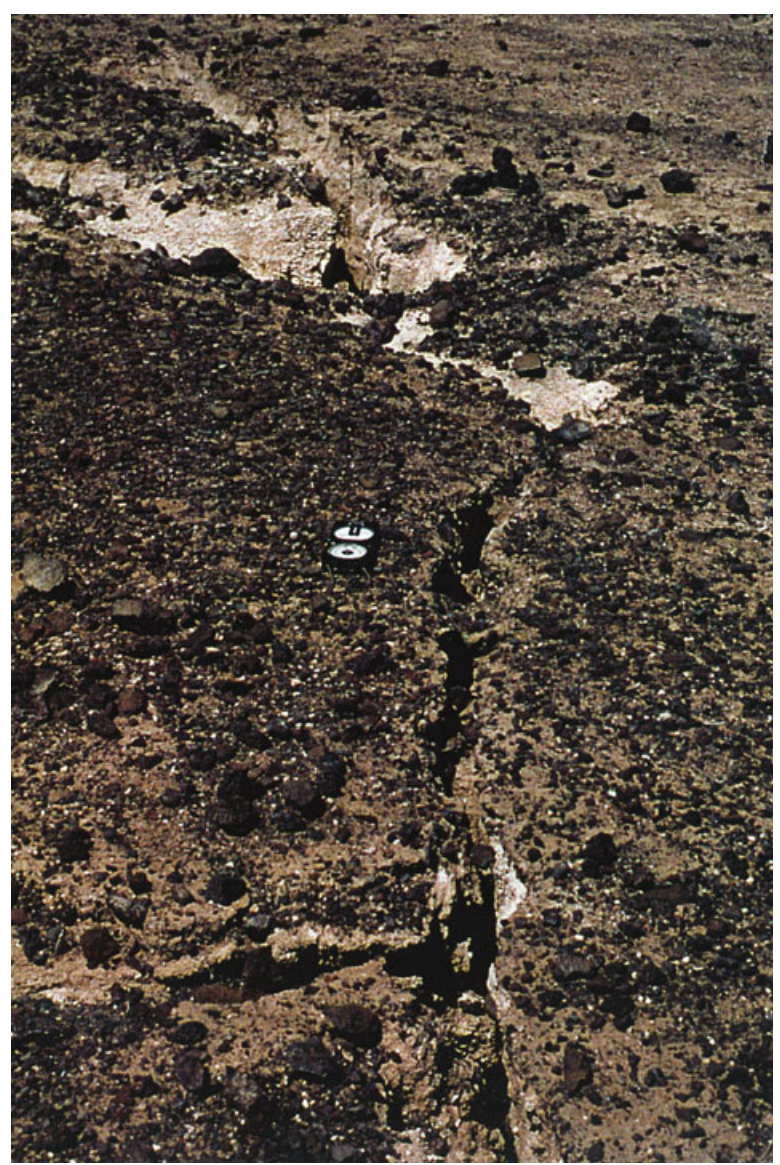

Fig. 15.22 Ruptures associated with the 1989 Dobi seismic sequence (after Jacques et al. 2011)
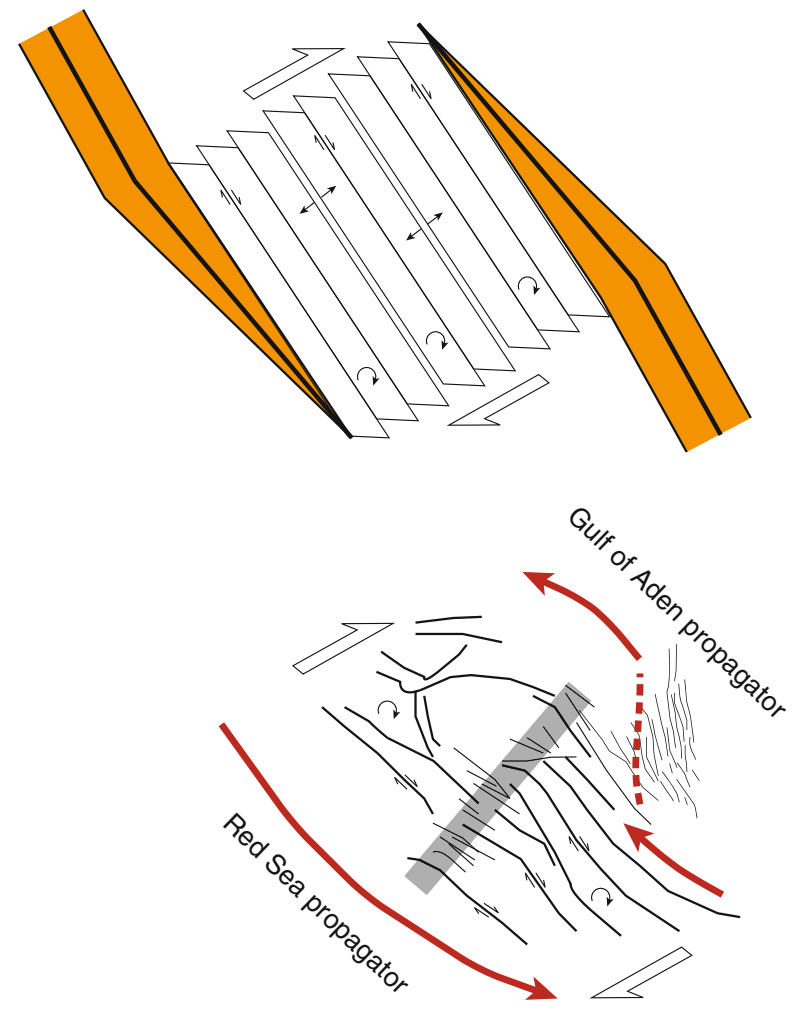

Fig. 15.23 Top panel Model of bookshelf faulting, in which rift propagation in opposite directions induces small-rigid blocks to rotate about vertical axis along rift-parallel faults that slip with a left-lateral component. Bottom panel Model of bookshelf faulting applied to central Afar; the grey line indicates a hypothesised major transversal structure (after Manighetti et al. 2001) 


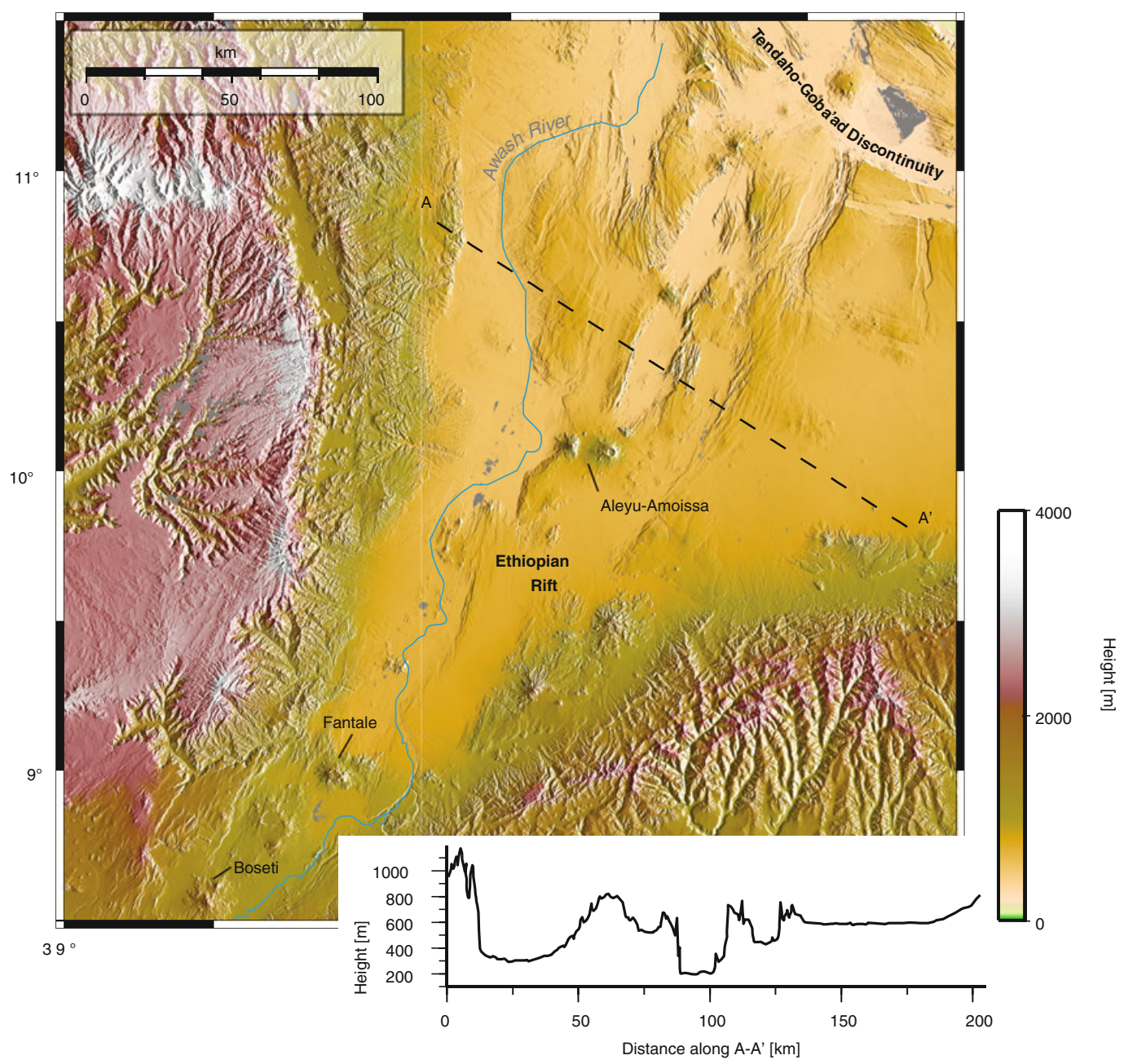

Fig. 15.24 Topography of southern Afar with major volcanic centres labelled. Bottom right panel shows a sample of topography on profile A-A' across the southern Afar floor

magma intrusion throughout the lithosphere beneath magmatic segments (e.g. Bastow et al. 2011), with extension facilitated and accommodated by a combination of magmatic intrusion, diking and faulting (e.g. Keir et al. 2006b). According to Kurz et al. (2007), the architecture and morphology of the magmatic segments are symmetric around central acidic strato-volcanoes, where the deformation pattern is characterised by small faults and a low fault density. The number of faults increases longitudinally away from the volcanic centres, such that maximal fault densities and the longest faults are observed at tip domains (Kurz et al. 2007). This reflects an along-axis change from magmatic deformation accommodated by diking at segment centres to mostly brittle deformation (faulting) at the tip domains.
The NE-NNE striking magmatic segments related to the Nubia-Somalia opening overprint previous NW-NNW striking faults, suggesting that extension in the northern MER postdates extension from initial opening of the southern Red Sea and Gulf of Aden (e.g. Tesfaye et al. 2003; Wolfenden et al. 2004). However, the NW-NNW trending structures still accommodate some volcano-tectonic activity, such as the intrusion of a $\sim \mathrm{N} 120^{\circ} \mathrm{E}$ striking, $\sim 6-\mathrm{km}$-long dike during May 2000 (Fig. 15.25; Keir et al. 2011). The intrusion occurred beneath the $\sim$ WNW striking AyeluAmoissa chain of aligned volcanic centres that dominate the morphology of the right stepping MER offset at $\sim 10^{\circ} \mathrm{N}$ (Fig. 15.25), but did not result in either volcanic eruptions or significant surface deformation (Keir et al. 2011). 


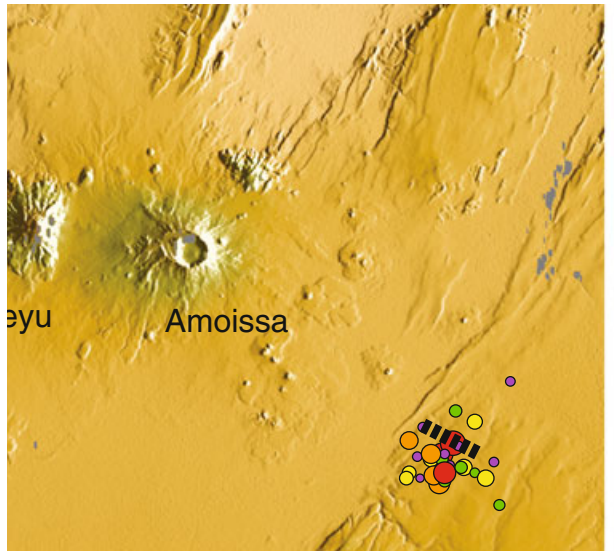

Fig. 15.25 Digital elevation model of the Ayelu-Amoissa volcanic system. Coloured circles are epicentres related to the May 2000 intrusion event; the black dashed line indicates the surface projection of

\subsection{Conclusions}

Afar is a spectacular example of how rifting at a complex triple junction can create and continuously modify the morphology of a region at different scales. Large-scale processes, initiated at depth in the Earth's mantle, have shaped the overall morphology of the area by inducing plateau uplift (up to $\sim 2 \mathrm{~km}$ ) and emplacement of voluminous flood basalt sequences at $\sim 30$ Ma. The subsequent subsidence of the Afar floor with respect to the surrounding elevated areas during initial Arabia-Africa rifting has created large fault escarpments that abruptly separate the rift floor from the plateaus. Although not characterised by significant current deformation and in places highly eroded, these escarpments still dominate the regional morphology.

The floor of Afar is primarily shaped by the tectonicmagmatic processes that developed since extension and became focused in a narrower zone of faults and volcanoes within the depression. In these rifts, continuing extension is accommodated by magma emplacement and normal faulting, which gives rise to a landscape dominated by spectacular fresh fault scarps and active volcanic edifices created during episodic tectonic, volcano-tectonic and purely volcanic events.

This morphology, and its along-axis variations, reflects the last phases of the protracted process leading to plate separation and the birth of a new oceanic basin. As break-up progresses, rift-related morphology changes from the narrow fault bound graben as in central Afar to the topographically prominent axial volcanic range in the Danakil depression where the relatively large volumes of erupted material show that a marked increase in rate of basaltic volcanism characterises the final stages of continental break-up. Here, the accumulation of thick sequences of basalt flows and evaporites represents a modern analogue for the processes responsible for the development of volcanic rifted margins worldwide.

\section{References}

Acocella V (2006) Regional and local tectonics at Erta Ale caldera, Afar (Ethiopia). J Struct Geol 28:1808-1820

Acocella V (2010) Coupling volcanism and tectonics along divergent plate boundaries: collapsed rifts from central Afar, Ethiopia. Geol Soc Am Bull 122:1717-1728

Acocella V, Abebe B, Korme T, Barberi F (2008) Structure of Tendaho Graben and Manda Hararo Rift: implications for the evolution of the southern Red Sea propagator in Central Afar. Tectonics 27: TC4016. http://dx.doi.org/10.1029/2007TC002236

Acocella V, Bekele A, Coltorti M (eds) (2011) Pre-conference excursion guide: Tectonic Landforms and Volcanism in the Southern Afar. Iag regional conference 2011 geomorphology for human adaptation to changing tropical environments Addis Ababa, Ethiopia, 18-22 Feb 2011

Audin J, Vellutini PJ, Coulon C, Piguet P, Vincent J (1990) The 19281929 eruption of Kammourta volcano. Evidence of tectonomagmatic activity in Manda-Inakir rift and comparison with the Asal rift, Afar Depression, Republic of Djibouti. Bull Volcanol 52:551-561

Ayele A, Keir D, Ebinger C, Wright TJ, Stuart GW, Buck RW, Jacques E, Ogubazghi G, Sholan J (2009) September 2005 mega-dike emplacement in the Manda-Harraro nascent oceanic rift (Afar Depression). Geophys Res Lett 36: L20306. http://dx.doi.org/10. 1029/2009GL039605

Ayalew D, Marty B, Barbey P, Yirgu G, Ketefo E (2006) Temporal compositional variation of syn-rift rhyolites along the western margin of the southern Red Sea and northern Main Ethiopian Rift In: Yirgu G, Ebinger CJ, Maguire PKH (eds) The Afar Volcanic Province within the East African Rift System. Geol Soc Spec Pub 259:121-130

Ayele A, Stuart G, Bastow I, Keir D (2007) The August 2002 earthquake sequence in north Afar: insights into the neotectonics of the Danakil microplate. J Afr Earth Sci 40:70-79 
Barberi F, Varet J (1970) The Erta Ale volcanic range (Danakil depression, northern Afar, Ethiopia). Bull Volcanol 34:848-917

Barberi F, Varet J (1977) Volcanism of Afar: small-scale plate tectonics implications. Geol Soc Am Bull 88:1251-1266

Barberi F, Ferrara G, Santacroce R, Varet J (1975) Structural evolution of the Afar triple junction. In: Pilger A, Rosler A (eds) Afar Depression of Ethiopia. Schweizerbart, Stuttgart, pp 39-54

Bastow I, Keir D (2011) The protracted development of the continentocean transition in Afar. Nat Geosci 4:248-250

Bastow ID, Nyblade AA, Stuart GW, Rooney TO, Benoit MH (2008) Upper mantle seismic structure beneath the Ethiopian hot spot: rifting at the edge of the African low-velocity anomaly. Geochem Geophys Geosyst 9:Q12022. doi:10.1029/2008GC002107

Bastow ID, Keir D, Daly E (2011) The Ethiopia Afar Geoscientific Lithospheric Experiment (EAGLE): probing the transition from continental rifting to incipient seafloor spreading. Geol Soc Am Spec Pap 478:51-76

Benoit M, Nyblade A, VanDecar J (2006) Upper mantle P wavespeed variations beneath Ethiopia and the origin of the Afar hotspot. Geology 34:329-332

Beyene A, Abdelsalam MG (2005) Tectonics of the Afar Depression: a review and synthesis. J Afr Earth Sci 41:41-59

Bilham R, Bendick R, Larson K, Mohr P, Braun J, Tesfaye S, Asfaw L (1999) Secular and tidal strain across the Main Ethiopian Rift. Geophys Res Lett 26:2789-2792

Boccaletti M, Bonini M, Mazzuoli R, Abebe B, Piccardi L, Tortorici L (1998) Quaternary oblique extensional tectonics in the Ethiopian Rift (Horn of Africa). Tectonophysics 287:97-116

Bonatti E, Emiliani C, Ostlung G, Rydell H (1971) Final desiccation of the Afar rift, Ethiopia. Science 172:468-469

Cattin R, Doubre C, de Chabalier J-B, King G, Vigny C, Avouac J-P, Ruegg J-C (2005) Numerical modelling of quaternary deformation and post-rifting displacement in the Asal-Ghoubbet (Djibouti, Afar). Earth Planet Sci Lett 239:352-367

Chorowicz J, Collet B, Bonavia F (1999) Left-lateral strike-slip tectonics and gravity induced individualisation of wide continental blocks in the western Afar margin. Eclogae Geol Helv 92:149-158

Corti G (2012) Evolution and characteristics of continental rifting: analogue modeling-inspired view and comparison with examples from the East African Rift System. Tectonophysics 522-523:1-33

Doubre C, Manighetti I, Dorbath L, Dorbath C, Bertil D, Delmond JC (2007) Crustal structure and magmato-tectonic processes in an active rift (Asal-Ghoubbet, Afar, East Africa): 2. Insights from the 23-year recording of seismicity since the last rifting event. J Geophys Res 112:B05406. doi:10.1029/2006JB004333

Ebinger C, Sleep NH (1998) Cenozoic magmatism in central and east Africa resulting from impact of one large plume. Nature 395: $788-791$

Ebinger C, Casey M (2001) Continental breakup in magmatic provinces: an Ethiopian example. Geology 29:527-530

Ebinger C, Ayele A, Keir D, Rowland J, Yirgu G, Wright T, Belachew M, Hamling I (2010) Length and timescales of rift faulting and magma intrusion: the Afar rifting cycle from 2005 to present. Ann Rev Earth Planet Sci 38:439-466

Ferguson DJ, Barnie TD, Pyle DM, Oppenheimer C, Yirgu G, Lewi E, Kidane T, Carn S, Hamling I (2010) Recent rift-related volcanism in Afar, Ethiopia. Earth Planet Sci Lett 292:409-418

Field L, Barnie T, Blundy J, Brooker RA, Keir D, Lewi E, Saunders K (2012) Integrated field, satellite and petrological observations of the November 2010 eruption of Erta Ale. Bull Volcanol 74:2251-2271

Fubelli G, Dramis F (2011) Coseismic surface faulting in the Kara Kore area (Wollo) caused by the May 29, 1961 Earthquake. In: Acocella V, Bekele A, Coltorti M (eds) Pre-conference excursion guide: tectonic landforms and volcanism in the Southern Afar. Iag regional conference 2011 geomorphology for human adaptation to changing tropical environments Addis Ababa, Ethiopia, 18-22 Feb 2011 pp 38-42

Furman T, Bryce J, Hanan B, Yirgu G, Ayalew D (2006) Heads and tails: 30 years of the Afar plume. In: Yirgu G, Ebinger CJ, Maguire PKH (eds) The Afar Volcanic Province within the East African Rift System. Geol Soc Lond Spec Publ 259:95-119

Gasse F (1991) Tectonic and climatic controls on lake distribution and environments in Afar from Miocene to Present. In: Katz B (ed) Lacustrine basin exploration: case studies and modern analogs. AAPG Mem 50:19-41

Gouin P (1979) Earthquake history of Ethiopia and the Horn of Africa. Int Develop Res Centre, Ottawa, Publ 118

Grandin R, Socquet A, Binet R, Klinger Y, Jacques E, de Chabalier JB, King GCP, Lasserre C, Tait S, Tapponnier P, Delorme A, Pinzuti P (2009) September 2005 Manda Hararo-Dabbahu rifting event, Afar (Ethiopia): constraints provided by geodetic data. J Geophys Res 114:B08404. doi:10.1029/2008JB005843

Grandin R, Socquet A, Jacques E, Mazzoni N, de Chabalier J-B, King GCP (2010) Sequence of rifting in Afar (Manda-Hararo rift, Ethiopia, 2005-2009): timespace evolution and interactions between dikes from InSAR and static stress change modeling. J Geophys Res 115:B10413. doi:10.1029/2009JB000815

Hansen S, Nyblade A, Benoit M (2012) Mantle structure beneath Africa and Arabia from adaptively parameterized P-wave tomography: implications for the origin of Cenozoic Afro-Arabian tectonism. Earth Planet Sci Lett 319:23-34

Hayward N, Ebinger C (1996) Variations in the along-axis segmentation of the Afar rift system. Tectonics 15:244-257

Hofmann C, Courtillot V, Féraud G, Rochette P, Yirgu G, Ketefo E, Pik R (1997) Timing of the Ethiopian flood basalt event and implications for plume birth and global change. Nature 389:838-841

Hutchinson RW, Engels GG (1972) Tectonic evolution of the southern Red Sea and its possible significance to older rifted continental margins. Geol Soc Am Bull 83:2989-3002

Hussein B, Chandrasekharam D, Chandrasekhar V, Jalludin M (2013) Geochemistry of thermal springs around Lake Abhe, Western Djibouti. Int J Sustain Energ. doi:10.1080/14786451.2013.813027

Jacques E, Kidane T, Tapponnier P, Manighetti I, Gaudemer Y, Meyer B, Ruegg JC, Audin L, Armijo R (2011) Normal faulting during the August 1989 Earthquakes in Central Afar: sequential triggering and propagation of rupture along the Dôbi Graben. Bull Seis Soc Am 101:994-1023

Kazmin V (compiler) (1972) Geological map of Ethiopia (1:2,000,000). Ethiopian geological survey, Ministry of Mines and Energy Resources, Addis Ababa

Kazmin V, Seife MB, Nicoletti M, Petrucciani C (1980) Evolution of the northern part of the Ethiopian Rift. In: Geodynamic evolution of the Afro-Arabian Rift System, Accademia Nazionale Dei Lincei, Atti dei Convegni Lincei 47:275-292

Keir D, Stuart G, Jackson A, Ayele A (2006a) Local earthquake magnitude scale and seismicity rate for the Ethiopian Rift. Bull Seis Soc Am 96:2221-2230

Keir D, Ebinger C, Stuart G, Daly E, Ayele A (2006b) Strain accommodation by magmatism and faulting as rifting proceeds to breakup: seismicity of the northern Ethiopian rift. J Geophys Res 111(B5):B05314. doi:10.1029/2005JB003748

Keir D, Hamling IJ, Ayele A, Calais E, Ebinger C, Wright TJ, Jacques E, Mohamed K, Hammond JOS, Belachew M, Baker E, Rowland JV, Lewi E, Bennati L (2009) Evidence for focused magmatic accretion at segment centers from lateral dike injections captured beneath the Red Sea rift in Afar. Geology 37:59-62

Keir D, Pagli C, Bastow I, Ayele A, Ababa E (2011) The magmaassisted removal of Arabia in Afar: evidence from dike injection in the Ethiopian rift captured using InSAR and seismicity. Tectonics 30 (2):TC2008. doi:10.1029/2010TC002785 
Keir D, Bastow I, Pagli C, Chambers E (2013) The development of extension and magmatism in the Red Sea rift of Afar. Tectonophysics 607:98-114

Kurz T, Gloaguen R, Ebinger C, Casey M, Abebe B (2007) Deformation distribution and type in the Main Ethiopian Rift (MER): a remote sensing study. J Afr Earth Sci 48:100-114

Lahitte P, Gillot PY, Courtillot V (2003) Silicic central volcanoes as precursors to rift propagation: the Afar case. Earth Planet Sci Lett 207:103-116

Le Gall B, Ahmed Daoud M, Rolet J, Moussa Egueh N (2011) Largescale flexuring and antithetic extensional faulting along a nascent plate boundary in the SE Afar rift. Terra Nova 23:416-420

Leroy S, Razin F, Autin J, Bache F, d'Acremont E, Watremez L, Robinet J, Baurion C, Denèle Y, Bellahsen N, Lucazeau F, Rolandone F, Rouzo S, Serra Kiel J, Robin C, Guillocheau F, Tiberi C, Basuyau C, Beslier M-O, Ebinger C, Stuart G, Ahmed A, Khanbari K, Al Ganad I, de Clarens P, Unternehr P, Al Toubi A, Al Lazki A (2012) From rifting to oceanic spreading in the Gulf of Aden: a synthesis. Arab J Geosci. http://dx.doi.org/10.1007/s12517-011-0475-4

Makris J, Ginzburg A (1987) The Afar Depression: transition between continental rifting and sea floor spreading. Tectonophysics 141: 199-214

Manighetti I, Tapponnier P, Gillot PY, Jacques E, Courtillot V, Armijo R, Ruegg JC, King GCP (1998) Propagation of rifting along the ArabiaSomalia boundary: into Afar. J Geophys Res 103(B3):4947-4974

Manighetti I, Tapponnier P, Courtillot V, Gallet Y, Jacques E, Gillot PY (2001) Strain transfer between disconnected, propagating rifts in Afar. J Geophys Res 106:13613-13665

McClusky S, Reilinger R, Ogubazghi G, Amleson A, Healeb B, Vernant P, Sholan J, Fisseha S, Asfaw L, Bendick R, Kogan L (2010) Kinematics of the southern Red Sea-Afar Triple junction and implications for plate dynamics. Geophys Res Lett 37:L05301. doi:10.1029/2009GL041127

Medynski S, Pik R, Burnard P, Williams A, Vye-Brown C, Ferguson D, Blard P-H, France L, Yirgu G, Seid JI, Ayalew D, Calvert A (2013) Magmatic cycles and development of rift topography of the Manda-Hararo segment (Afar): Insights from cosmogenic $3 \mathrm{He}$ Earth Planet Sci Lett 367:133-145

Mohr P (1978) Afar. Ann Rev Earth Planet Sci 6:145-172

Mohr P (1987) Patterns of faulting in the Ethiopian Rift Valley. Tectonophysics 143:169-179

Morton WH, Black R (1975) Crustal attenuation in Afar. In: Pilger A, Rosler A (eds) Afar Depression of Ethiopia. Schweizerbart, Stuttgart, pp 55-61

Nobile A, Pagli C, Keir D, Wright TJ, Ayele A, Ruch J, Acocella V (2012) Dike-fault interaction during the 2004 Dallol intrusion at the northern edge of the Erta Ale Ridge (Afar, Ethiopia). Geophys Res Lett. http://dx.doi.org/10.1029/2012GL053151

Nyblade AA, Robinson SW (1994) The African superswell. Geophys Res Lett 21:765-768

Pagli C, Wright TJ, Ebinger CJ, Yun S-H, Cann JR, Barnie T, Ayele A (2012) Shallow axial magma chamber at the slow-spreading Erta Ale Ridge. Nat Geosci 5:284-288

Pagli C, Hua W, Wright TJ, Calais E, Lewi E (2014) Current plate boundary deformation of the Afar rift from a 3D velocity field inversion of InSAR and GPS. J Geophys Res (in press)

Pik R, Marty B, Carignan J, Lavé J (2003) Stability of the Upper Nile drainage network (Ethiopia) deduced from (U-Th)/He thermochronometry: implications for uplift and erosion of the Afar plume dome. Earth Planet Sci Lett 215:73-88

Pizzi A, Pontarelli L (2007) Geometria del rift nel margine meridionale dell'Afar: Dire Dawa (Etiopia). Rend Soc Geol It $4: 288-289$

Ritsema J, Deuss A, van Heijst H, Woodhouse J (2011) S40RTS: a degree-40 shear-velocity model for the mantle from new Rayleigh wave dispersion, teleseismic traveltime and normal-mode splitting function measurements. Geophys J Int 184:1223-1236

Rogers N, Macdonald R, Fitton J, George R, Smith R, Barreiro B (2000) Two mantle plumes beneath the East African rift system: Sr, $\mathrm{Nd}$ and $\mathrm{Pb}$ isotope evidence from Kenya Rift basalts. Earth Planet Sci Lett 176:387-400

Rooney T, Herzberg C, Bastow I (2012a) Elevated mantle temperature beneath East Africa. Geology 40:27-40

Rooney T, Hanan BB, Graham DW, Furman T, Blichert-Toft J, Schilling J-G (2012b) Upper mantle pollution during Afar PlumeContinental rift interaction. J Petrol 53:365-389

Rooney T, Mohr P, Dosso P, Hall (2013) Upper mantle pollution during Afar Plume-Continental rift interaction. Geochim Cosmochim Acta 102(1):6588. doi:10.1016/j.gca.2012.08.019

Rowland JR, Baker E, Ebinger C, Keir D, Kidane T, Biggs J, Hayward N, Wright T (2007) Fault growth at a nascent slow spreading ridge: 2005 Dabbahu rifting episode, Afar. Geophys J Int 171:1226-1246

Ruegg JC, Lépine JC, Tarantola A (1979) Geodetic measurements of rifting associated with a seismo-volcanic crisis in Afar. Geophys Res Lett 6:817-820

Siebert L, Simkin T, Kimberly P (2010) Volcanoes of the world, 3rd edn. University of California Press, Berkeley

Soliva R, Schultz RA (2008) Distributed and localized faulting in extensional settings: insight from the North Ethiopian Rift-Afar transition area. Tectonics 27:TC2003. doi:10.1029/2007TC002148

Souriot T, Brun J-P (1992) Faulting and block rotation in the Afar triangle, East Africa: the Danakil "crank-arm" model. Geology 20:911-914

Talbot CJ (2008) Hydrothermal salt-but how much? Mar Petrol Geol 25:191-202

Tapponnier P, Armijo R, Manighetti I, Courtillot V (1990) Bookshelf faulting and horizontal block rotations between overlapping rifts in southern Afar. Geophys Res Lett 17:1-4

Tarantola A, Ruegg JC, Lépine JC (1979) Geodetic evidence for rifting in Afar: a brittle-elastic model of the behaviour of the lithosphere. Earth Planet Sci Lett 45:435-444

Tesfaye S, Harding D, Kusky T (2003) Early continental breakup boundary and migration of the Afar triple junction, Ethiopia. Geol Soc America Bull 115:1053-1067

Thurmond AK, Abdelsalam MG, Thurmond JB (2006) Optical-radarDEM remote sensing data integrated for geological mapping in the Afar Depression, Ethiopia. J Afr Earth Sci 44:119-134

Waltham T (2010) Afar triangle: rift valleys and volcanoes over plate divergence. In: Migon P (ed) Geomorphological Landscapes of the World. Springer Science+Business Media, pp 183-190

Williams FM, Williams MAJ, Aumento F (2004) Tensional fissures and crustal extension rates in the northern part of the Main Ethiopian Rift. J Afr Earth Sci 38:183-197

Wolfenden E, Ebinger C, Yirgu G, Deino A, Ayalew D (2004) Evolution of the northern main Ethiopian rift: birth of a triple junction. Earth Planet Sci Lett 224:213-228

Wolfenden E, Ebinger C, Yirgu G, Renne P, Kelley S (2005) Evolution of a volcanic rifted margin: Southern Red Sea, Ethiopia. Geol Soc Am Bull 117:846-864

Wright T, Ebinger C, Biggs J, Ayele A, Yirgu G, Keir D, Stork A (2006) Magma-maintained rift segmentation at continental rupture in the 2005 Afar dyking episode. Nature 442:291-294

Wright TJ, Sigmundsson F, Pagli C, Belachew M, Hamling IJ, Brandsdóttir B, Keir D, Pedersen R, Ayele A, Ebinger C, Einarsson P, Lewi E, Calais E (2012) Geophysical constraints on the dynamics of spreading centres from rifting episodes on land. Nat Geosci 5:242-250 Zanettin B, Justin-Visentin E (1975) Tectonical and volcanological evolution of the western Afar margin (Ethiopia). In: Pilger A, Rosler A (eds) Afar Depression of Ethiopia. Schweizerbart, Stuttgart pp 300-309 